Portland State University

PDXScholar

Winter 4-19-2018

\title{
The Mind of a Medieval Inquisitor: an Analysis of the 1273 Compilatio de Novu Spiritu of Albertus Magnus
}

Emily McKinstry

Portland State University

Follow this and additional works at: https://pdxscholar.library.pdx.edu/open_access_etds

Part of the History Commons, and the Religion Commons

Let us know how access to this document benefits you.

\section{Recommended Citation}

McKinstry, Emily, "The Mind of a Medieval Inquisitor: an Analysis of the 1273 Compilatio de Novu Spiritu of Albertus Magnus" (2018). Dissertations and Theses. Paper 4356.

https://doi.org/10.15760/etd.6249

This Thesis is brought to you for free and open access. It has been accepted for inclusion in Dissertations and Theses by an authorized administrator of PDXScholar. Please contact us if we can make this document more accessible: pdxscholar@pdx.edu. 
The Mind of a Medieval Inquisitor: An Analysis of the 1273 Compilatio de Novu Spiritu of Albertus Magnus

\author{
by \\ Emily McKinstry
}

A thesis submitted in partial fulfillment of the requirement for the degree of

Master of Arts

In

History

Thesis Committee:

John Ott, Chair

Desmond Cheung

David A. Johnson

Loren Spielman

Portland State University

2018 
(C) 2018, Emily McKinstry 


\begin{abstract}
The fight against heresy in medieval Europe has fascinated scholars for centuries. Innumerable books, movies, and even video games have been made about this struggle to combat heresy in the Middle Ages. Despite this apparent fascination with the subject, our understanding of medieval heretics and the inquisitors who prosecuted them remains murky. What we do know is that many medieval people lost their lives, while others were punished with imprisonment or excommunication. We also know that many others dedicated their lives to rooting out what they believed was the evil of heresy among the populace. And we know that fear of the spread of heresy was rampant within the later medieval Church. But what constituted heresy? Who were the people accused as heretics? And why were they accused? These are questions that are still debated and discussed within the scholarly community.

As a contribution to the study of heresy, I have chosen to analyze one particular document and its author. This document, the Compilatio de Novu Spiritu, written by Albertus Magnus around 1273, consists of a list of ninetyseven heretical beliefs attributed to heretics in the Swabian Ries. It has been previously studied as marking the beginning of the "Free Spirit" heresy. However, many of the previous assumptions about the heresy of the Free Spirit have been questioned by more recent scholarship, including whether the sect existed at all. Instead, the heresy of the Free Spirit is now generally acknowledged to be closely related to medieval mysticism, and practiced by only a few individuals or possibly small groups. Therefore, the significance of
\end{abstract}


the Compilatio has changed. I will re-examine the document, analyzing it not as a precursor to a later religious movement that preached that souls united with God can act with moral impunity, but as a window into the mind of its inquisitorial author, Albertus Magnus.

The intent of this study is to better understand the thinking of the inquisitors who fought against heresy, focusing particularly on the Compilatio and its author, Albertus Magnus (c.1200 - 1280). The methodology of the study of heresy has elicited significant debate among historians, and these issues need to be addressed prior to an analysis of this document. Therefore, I will discuss the historiography of medieval heresy and address the major disagreements within the field in this introduction. In Chapter 1 , I set forth as historical background the religious situation in medieval Europe at the time the Compilatio was written. The medieval Church spent considerable time and resources in the struggle against heresy, so I will also examine the Church's response to heresy in this chapter. In the second chapter, I address how Albertus responded to the statements enumerated in the document and in particular, the manner in which he cites early church heresies. Lastly, in the final chapter, I explore how Albertus Magnus used early church writers such as Augustine and Gregory for substantiation throughout the document. Specifically, I analyze how Augustine, Gregory, and Albertus treat the sin of pride. 


\section{Table of Contents}

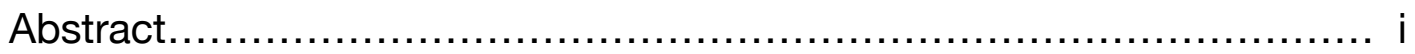

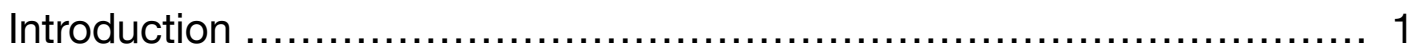

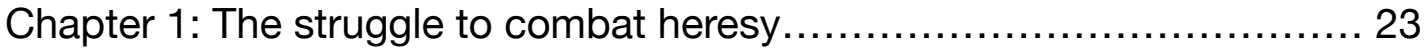

Chapter 2: Inquisitorial Tactics............................................ 47

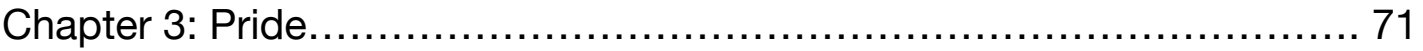

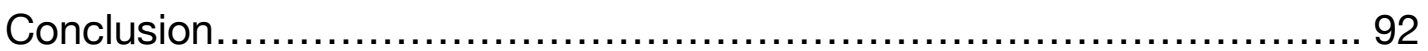

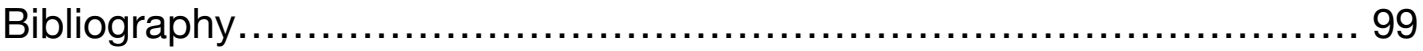




\section{Introduction: Difficulties inherent in the study of heresy}

The fight against heresy in medieval Europe has fascinated scholars for centuries. Innumerable books, movies, and even video games have been made about this struggle to combat heresy in the Middle Ages. Despite this apparent fascination with the subject, our understanding of medieval heretics and the inquisitors who prosecuted them remains murky. What we do know is that many medieval people lost their lives, while others were punished with imprisonment or excommunication. We also know that many others dedicated their lives to rooting out what they believed was the evil of heresy among the populace. And we know that fear of the spread of heresy was rampant within the medieval Church. But what constituted heresy? Who were the people accused as heretics? And why were they accused? These are questions that are still debated and discussed within the scholarly community.

As a contribution to the study of heresy, I have chosen to analyze one particular document and its author. This document, the Compilatio de Novu Spiritu was written by Albertus Magnus around 1273 is a list of ninety-seven heretical beliefs attributed to heretics in the Swabian Ries. It has been previously studied as marking the beginning of the "Free Spirit" heresy. However, many of the previous assumptions about the heresy of the Free Spirit have been questioned by more recent scholarship, including whether the sect existed at all. Instead, the heresy of the Free Spirit is now generally acknowledged to be closely related to medieval mysticism, and practiced by only a few individuals or possibly small groups. Therefore, the significance of 
the Compilatio has changed. I will re-examine the document, analyzing it not as a precursor to a later religious movement that preached that souls united with God can act with moral impunity, but as a window into the mind of its medieval inquisitor.

The intent of this study is to better understand the thinking of the inquisitors who fought against heresy, focusing particularly on the Compilatio and its author, Albertus Magnus (c.1200 - 1280). The methodology of the study of heresy has elicited significant debate among historians, and these issues need to be addressed prior to an analysis of this document. Therefore, I will discuss the historiography of medieval heresy and address the major disagreements within the field in this introduction. In Chapter 1 , I set forth as historical background the religious situation in medieval Europe at the time the Compilatio was written. The medieval Church spent considerable time and resources in the struggle against heresy, so I will also examine the Church's response to heresy in this chapter. In the second chapter, I address how Albertus responded to the statements enumerated in the document and in particular, the manner in which he cites early church heresies. Lastly, in the final chapter I explore how Albertus Magnus used early church writers such as Augustine and Gregory for substantiation throughout the document. Specifically, I analyze how Augustine, Gregory, and Albertus treat the sin of pride. 


\section{The Compilatio - Basic Facts}

The Compilatio consists of ninety-seven numbered statements, of about one to three sentences each, which are purported to have been compiled from an inquisitorial trial of heretics in the Swabian Ries, a region in southwest Germany. Most statements begin with the words "It is said that" before describing a heretical belief. Many of the beliefs are then specifically denounced as heretical by Albertus, and he frequently cites the Bible, Augustine, or other early Church writers to support these claims. Additionally, Albertus attributes many of the heretical beliefs in the document to early Church heresies, such as Manichaeism and Pelagianism.

The original version of the document, referenced in Johannes Nider's Formicarius, written in about 1435 , was purportedly in a manual composed by Albertus himself. However, that manual does not survive. A second version of the Compilatio does exist in the "Passau Anonymous," which is a collection of uncertain authorship consisting of documents written against Jews and heretics. ${ }^{1}$ This latter version contains twenty-nine additional heretical statements beyond the original ninety-seven, which I have not included in this thesis. ${ }^{2}$ Three manuscript copies of the Passau Anonymous have been preserved in the Bavarian State Library. The edition I have used was transcribed

\footnotetext{
1 Herbert Grundmann, Religious Movements in the Middle Ages: The Historical Links between Heresy, the Mendicant Orders, and the Women's Religious Movement in the Twelfth and Thirteenth Century, with the Historical Foundations of German Mysticism, trans. Steven Rowan (Notre Dame: University of Notre Dame Press, 1995), 170.

2 I have chosen not to include these twenty-nine additional statements because they were not in the original version of the document. The additional statements, however, do agree in general form and content with the original ninety-seven statements.
} 
by Wilhelm Preger from the oldest of these copies in a compilation of other documents on German mysticism in the Middle Ages. Preger transcribed it in its original Latin. No translation of the document has yet been made, so the translations in this thesis are my own.

The author, date of composition, and purpose of the document have all elicited debate among historians. Scholars have long expressed disagreement over authorship of the Compilatio. Irven Resnick and Kenneth Kitchell include this document in their annotated bibliography on Albertus and his works, but list it as a "work of uncertain attribution." 3 They cite William Preger's article, which attributes the Compilatio to David of Augsburg, the German mystic and Franciscan friar. ${ }^{4}$ However, a different source cited within their bibliography, "Albert der Grosse und der Tractates de inquisitione" by Franz Pelster, treats the issue of authorship and ultimately contends that the document was written by Albertus Magnus, not David of Augsburg. ${ }^{5}$ John Freed, in his monograph The Friars and German Society in the Thirteenth Century, also includes a brief mention of the Compilatio. He does not attribute it to a specific author, rather crediting the "friars" in general. ${ }^{6}$

3 Irvin M. Resnick and Kenneth F. Kitchell, Jr., Albert the Great: Selectively Annotated Bibliography (1900-2000) (Tempe: Arizona Center for Medieval and Renaissance Studies, 2004), 69.

4 Wilhelm Preger, "Der Traktat des David von Augsburg über die Waldenser, Abhandlungen der Bayerischen Akademie der Wissenschaften, Historische Klasse 18 (1878): 181-235.

5 Franz Pelster, "Albert der Grosse und der Tractatus de inquisitione haereticorum," Zeitschrift Für Katholische 45 (1921): 609-627.

6 John B. Freed, The Friars and German Society in the Thirteenth Century (Cambridge: The Medieval Academy of America, 1977), 145. 
Most other scholars, however, attribute the authorship of the Compilatio to Albertus Magnus, the well-known Dominican friar, German bishop, and eventually Catholic saint and Doctor of the Church. Herbert Grundmann, in his book Religious Movements in the Middle Ages, unequivocally lists Albertus Magnus as the author of the work. He cites as evidence the Formicarius, written by Johannes Nider in 1435, which lists Albertus Magnus as the author of the text. ${ }^{7}$ Robert Lerner also discusses the Compilatio in his detailed study of the Free Spirit movement. Like Grundmann, Lerner attributes the text to Albertus Magnus without any debate. ${ }^{8}$ Lerner cites as evidence the heading of an early copy of the document in a manuscript from Mainz dating from the end of the thirteenth or early fourteenth century, which states that "this is the determination of Master Albert, formerly Bishop of Regensburg, Order of Preachers, concerning the articles of the heresy found in the Ries, in the diocese of Augsburg."9 Additionally, Michael Bailey, in his work Battling Demons: Witchcraft, Heresy, and Reform in the Late Middle Ages, decisively lists Albertus Magnus as the author of the work. His book discusses the works of Johannes Nider, who, Bailey argues, "based his description of widespread Free Spirit heresy" on the list of heretical statements by "the great Dominican theologian Albertus Magnus."10 Based upon

\footnotetext{
7 Grundmann, Religious Movements in the Middle Ages, 170.

8 Robert E. Lerner, The Heresy of the Free Spirit in the Later Middle Ages (Berkeley: University of California Press, 1972), 14.

9 lbid.
}

10 Michael Bailey, Battling Demons: Witchcraft, Heresy, and Reform in the Late Middle Ages (University Park: The Pennsylvania State University Press, 2003), 56. 
the primary source evidence and the secondary source scholarship, I will follow current scholarly consensus and attribute the document to Albertus Magnus.

Albertus Magnus is perhaps best known for his twenty-one volume enterprise which summarized "through systematic paraphrase" the entire works of Aristotle in order to make them more accessible to scholars of his own age. ${ }^{11}$ He was born the elder son of a military noble or knight sometime before 1200 in the Swabian town of Lauingen. ${ }^{12}$ In 1223, Jordan of Saxony, Master General of the Dominican leaders, brought him into the Dominican Order. He studied in Cologne and then in Paris, where he was the first German to hold one of the Dominican chairs at the University. It was around this time that he began his commentaries on Aristotle and also took on Thomas Aquinas as his student. ${ }^{13}$ In 1256, he was summoned to the papal curia of Anagni to defend the mendicant orders against attacks from William of Saint-Amour. Historians describe Albertus as playing a pivotal role in resolving the controversy in favor of the mendicant orders. ${ }^{14}$ In 1260, Albertus was appointed Bishop of Regensburg, a post which he was reluctant to take. Indeed, he served only a little over a year before resigning his position and returning to teaching. From 1263-1264, he was called by Pope Urban IV to preach the crusade against heresy in all Germanic speaking

\footnotetext{
11 James A. Weisheipl, "Albertus Magnus," in Dictionary of the Middle Ages, ed. Joseph Strayer, vol. 1 (New York: Charles Scribner's Sons, 1982), 127.

12 Alain de Libera, "Albertus Magnus, (1200-1280)," in Routledge Encyclopedia of Philosophy, vol. 1, ed. Edward Craig (London: Routledge Press, 1998), 145.

13 Clyde Lee Miller, "Albertus Magnus (ca. 1200-1280)," in Medieval Germany: An Encyclopedia, ed. John M. Jeep (New York: Garland Publishing, 2001), 8.
}

14 Weisheipl, "Albertus Magnus," 128. 
lands. ${ }^{15}$ Following this period, Albertus lectured at various Dominican houses in Germany, but also served as arbiter in Cologne between the archbishop and the citizens of the town until 1274. After this, historians debate whether Albertus made a trip back to Paris to defend Thomas Aquinas' views, but due to his advanced age many scholars express doubt about the veracity of this incident. ${ }^{16}$ The title of "great" was conferred upon Albertus during his lifetime and he was considered by his contemporaries to be a preeminent scholar. ${ }^{17}$ Albertus was a prolific writer, but following his death a large number of spurious works were attributed to him, both devotional and magical, which contributes to the confusion regarding his authorship of the Compilatio. ${ }^{18}$

The date the Compilatio was composed is also disputed by scholars. Herbert Grundmann includes a lengthy discussion of the dating of the document in Religious Movements. He disputes previous assertions that the document was composed prior to $1260 .{ }^{19}$ Instead, he contends that the investigation of the heresy in the Swabian Ries likely took place between 1270-1273 during a period of dispute between the Dominicans and Franciscans. He bases this assumption upon two articles in the Colmar Annals which depict instances of heresy in the Swabian Ries in 1270. Grudnmann links these reports of heresy with the heresy

\footnotetext{
15 Ibid., 129.

16 Henryk Anzulewicz, "Albertus Magnus, Saint," in Complete Dictionary of Scientific Biography, vol. 19 (Detroit: Charles Scribener's Sons, 2008), 38.

17 Weisheipl, “Albertus Magnus," 129.

18 lbid.

19 Grundmann, Religious Movements in the Middle Ages, 171.
} 
inquisition that Albertus is responding to in the Compliatio. ${ }^{20}$ According to this dating, the document would therefore have been composed sometime between 1270 and Albertus Magnus' death in 1280. John Freed also lists 1270 as the date of the heresy investigation in the Swabian Ries. ${ }^{21}$ Similarly, Robert Lerner dates the heresy investigation between 1270-1273 and contends that the document was written at some point after that and prior to Albert's death. ${ }^{22}$ In this paper, I will follow Grundmann and Lerner in dating the document between the years 1273 and 1280.

Historians seem to largely agree that the Compilatio was not composed during the actual inquisition of the Swabian heretics. Grundmann also contends that Albertus Magnus likely did not personally participate in the heresy investigation. ${ }^{23}$ Due to Albertus' previous appointment to preach the crusade in German-speaking lands, he certainly had relevant experience in the judgment and prosecution of heresy. ${ }^{24}$ Nevertheless, Grundmann describes the Compilatio as "an evaluation in which Albertus Magnus gives a purely academic judgement" on the statements of heretics "presented to him."25 Robert Lerner also argues that Albertus Magnus likely wrote the document secondhand. ${ }^{26} \mathrm{He}$ contends that

\footnotetext{
20 Ibid., 172.

21 Freed, The Friars and German Society, 145.

22 Lerner, The Heresy of the Free Spirit, 14.

23 Grundmann, Religious Movements in the Middle Ages, 173.

24 Weisheipl, “Albertus Magnus,” 128.

25 Ibid.

26 Lerner, The Heresy of the Free Spirit, 14.
} 
the purpose of the document was principally to classify and refute, as most of the statements are ascribed to ancient heresies. ${ }^{27}$ Therefore, Lerner classifies the document as a "scholastic exercise" written from afar rather than a transcript from the actual inquisitorial trial. ${ }^{28}$ This thesis will also consider that the Compilatio was written after the actual heresy investigation for the purpose of classifying and refuting the beliefs described in the document.

The religious situation in Germany, where Albertus Magnus served as prior and bishop, was distinct from the rest of western Europe. ${ }^{29}$ Richard Kieckhefer, in his work Repression of Heresy in Medieval Germany, contends that in Germany, heresy was not "perceived as such an overwhelming danger," nor did it occupy the same place of fear in the public consciousness that it did in other parts of Europe. ${ }^{30}$ Rather, Kieckhefer argues that most heretics in Germany were "scattered" and "effectively underground,"31 with the exception of the Waldensians, who were active in Germany in the twelfth and thirteenth centuries. The Waldensians did inspire some heresy hunts in Germany beginning in the 1200s. However, the overly zealous actions of the infamous inquisitor Conrad of Marburg led to a lull in heresy accusations after the 1230s, as he accused and

\footnotetext{
27 Ibid.

28 Ibid., 15.

29 Freed, The Friars and German Society, 227.

30 Richard Kieckhefer, Repression of Heresy in Medieval Germany (Philadelphia: University of Pennsylvania Press, 1979), 6.

31 lbid.
} 
executed many people on charges of heresy without evidence. ${ }^{32}$ Eventually, his accusation of a nobleman precipitated his own assassination. In the decades following this incident, during which the Compilatio was written, there were few accusations of heresy.

The political situation in Germany, however, was quite contentious during the thirteenth century. The Dominican and Franciscan presence in Germany had increased. ${ }^{33}$ As their numbers expanded, the friars frequently came into conflict with members of the secular clergy, especially during the latter half of the thirteenth century. ${ }^{34}$ Additionally, there was considerable political tension between the bishops and the German burghers in this period, and the friars were routinely utilized as mediators. ${ }^{35}$ John Freed, in his work Friars in German Society in Thirteenth Century, describes these events in detail, including Albertus Magnus' role in the proceedings. Albertus personally acted as arbitrator in a number of these disputes; his arbitration services were sought out by both sides. ${ }^{36}$ In 1271, he mediated a serious dispute in Cologne. Freed contends that while Albertus "sincerely tried to bring peace to a deeply troubled city," ${ }^{37}$ he also did uphold the "commercial and financial interests" of the burghers, with several

\footnotetext{
32 Ibid., 14.

33 Freed, The Friars and German Society, 22.

34 Ibid., 36.

35 Ibid., 39.

36 Ibid., 100-104.

37 Ibid., 105.
} 
of whom he had lifelong friendships. ${ }^{38}$ For Freed, the friars' involvement in these political disputes made it difficult to "preserve that detachment from earthly society which their self-professed role as the disciples of Christ demanded."39 Freed describes this politicization of the friars as a great tragedy, which represented "the failure of an ideal." 40 It was during this period of political strife, in which Albertus Magnus was directly involved, that he composed the Compilatio.

\section{The Study of Heresy - Orthodoxy \& Heterodoxy}

In order to understand medieval heresy one needs to also understand medieval orthodox religious beliefs and the relationship between orthodoxy and heterodoxy. Heresy is generally defined as a belief that is opposed to orthodox doctrine. The very definition of heresy, therefore, requires the existence of defined orthodoxy. Herbert Grundmann's seminal 1933 work helps make clear the paradoxically close connection between medieval orthodoxy and heretical religious movements. He discusses how earlier historiography, which largely approached the subject matter from a Catholic or Protestant viewpoint, analyzed heretical groups as separate and distinct from the Church. This scholarship searched for what made the beliefs of heretical groups different from those of the established Church. Grundmann, in contrast, argues for a

\footnotetext{
$38 \mathrm{lbid}$.

$39 \mathrm{lbid}$. 40 Ibid., 138.
} 
"panoramic vision of religious development in the Middle Ages." 41 His work contends that individual groups, both heretical and orthodox, stemmed from a "single religious movement." 42 Grundmann describes this as a "common family tree." ${ }^{33}$ This common ancestry, Grundmann argues, lies within the movement for "evangelical poverty and apostolic preaching," otherwise known as the vita apostolica. ${ }^{44}$ This is an important point that has shaped the study of heresy since the publication of Grundmann's work.

Scholars have since built upon Grundmann's assertions in order to argue that orthodoxy requires heterodoxy in order to define itself. For example, Jeffrey Russell has contended that dissent is the "inevitable companion" of orthodoxy. 45 He argues that the challenge heterodoxy presented to dogma actually helped define doctrine by forcing orthodoxy to absorb the new ideas or to deem them heretical.46 Malcom Lambert also describes how heresy assisted in the development of the early church by forcing the definition of what constituted doctrinal truth and what constituted heresy. 47 Lambert, like Grundmann,

\footnotetext{
41 Grundmann, Religious Movements in the Middle Ages, 3.

42 Ibid.

43 Ibid., 4.

44 Ibid.

45 Jeffrey Burton Russell, Dissent and Reform in the Early Middle Ages (Berkeley: University of California Press, 1965), 3.

46 Ibid., 249.

47 Malcolm Lambert, Medieval Heresy: Popular Movements from the Gregorian Reform to the Reformation, 3rd ed. (Malden, MA: Blackwell Pub., 2002), 1.
} 
contends that a study of heresy cannot be undertaken without examining orthodoxy as well, as the two are mutually dependent. 48

The relationship between orthodoxy and heterodoxy is therefore vital in my own analysis of the Compilatio. In order to understand Albertus' response to the heretical statements listed in the document, I need to first describe his own understanding of Christian doctrine as well as the spiritual trends evident in thirteenth century Europe. Albertus clearly possessed in-depth knowledge of early church writers, especially Augustine, which help define his understanding of orthodox doctrine. The heretical statements listed in the Compilatio display elements of the spiritual trends that were predominant in thirteenth-century Europe. Both Albertus' understanding of Christianity, as well as the current concerns of the established Church, helped to inform his response to the heretical statements within the text.

\section{The Study of Heresy - Historiography}

Heresy can be a difficult subject to approach because most of the primary sources that depict accused heretics were written by their accusers and examiners. While a few documents written by those accused of heresy have survived, records of most accused heretics exist only through the words of the inquisitors. This difficulty has helped to fuel strident historiographical debate among historians on how to interpret primary sources relating to medieval heresy. Scholarship on this topic has changed significantly over the past several decades, with earlier scholars accepting inquisitorial sources as accurate 
depictions of heretical sects, whereas more recent scholars deny the existence of heresy in the Middle Ages outside of the minds of inquisitors. This debate is relevant to my study because we have essentially no information on those Albertus accused of heresy in the Compilatio, other than the words that he, an inquisitor, wrote. This dearth of corroborating sources makes it very difficult to form an understanding of the heretics referred to in this document, as we have no evidence beyond this document that they even existed at all. Therefore, before I begin my analysis, it is necessary to address this historiographical debate, as it is directly relevant to the question of how to approach a study of the Compilatio.

Norman Cohn provides an example of the earlier tendency in scholarship to interpret primary source material literally. Although Cohn purports to examine the sources critically, he takes many accusations of heresy as proof of actual wrongdoing. His treatment of the Free Spirit Heresy provides an apt example. Although Cohn acknowledges that many scholars question the existence of an organized sect of "Free Spirits," he concludes that the Catholic Church's accounts of this heresy were "substantially correct." 49 Further, while Cohn concedes that accusations of promiscuity were commonly employed in the Middle Ages to discredit one's enemies, he gives credence to such accusations against the Free Spirits. He contends that such accusations present an "entirely convincing picture" of "eroticism" which serves as a "sign of spiritual

\footnotetext{
49 Norman Cohn, The Pursuit of the Millennium: Revolutionary Millenarians and Mystical Anarchists of the Middle Ages (London: Maurice Temple Smith, 1970), 149.
} 
emancipation."50 Although most modern scholars no longer give credence to Cohn's conclusions, it is worth noting his work as one end of the spectrum of historical scholarship on medieval heresy.

Jeffrey Burton Russell's 1965 work advanced a slightly different approach to the sources of medieval history. Russell more thoroughly discusses the difficulties involved in using sources. He explains that medieval writers frequently used what he terms "topoi," which he defines as "stock phrases," to assign blame "without much discretion." 51 He reasons that this makes it more difficult to determine if accusations of heresy and sexual promiscuity are real or fabricated.52 However, Russell ultimately contends that all accusations of heresy in the Middle Ages were rooted in fact to some degree. He claims that medieval men did not "use the term promiscuously," so that what is termed as heresy "usually really is dissent of one sort or another." 53 Russell widens the definition of heresy to include "deviations from the religious norms of medieval Catholicism," but he still gives credence to almost all other heresy charges.54 While Russell uses more discretion when interpreting primary source material, he still accepts many accusations as factual without sufficient contextualization.

\footnotetext{
50 Ibid., 151.

51 Russell, Dissent and Reform, 264.

52 lbid.

53 Ibid., 3.

54 Ibid.
} 
Robert Lerner, writing in 1972 about the heresy of the Free Spirit, distances himself from previous scholarship in his interpretation of primary source material. In his introduction, Lerner discusses the difficulties with sources on heresy. Importantly, he contends that scholars should never accept hostile sources as accurate depictions of medieval heresy, "no matter how seemingly independent they may be." 55 This presents a change from both Russell and Cohn, who accepted hostile sources to form their conclusions about medieval heretics. He advocates the use of inquisitorial records, which he acknowledges are better than hostile sources, but still require caution as the threat of torture, particularly after the middle of the thirteenth century, was ever-present and the records themselves were summations rather than dictations. ${ }^{56}$ Lerner contends that the best sources for examining the beliefs of medieval heretics are the heretics' own writings, which is where he focuses the most attention. 57 Lerner ultimately reaches the conclusion that the Free Spirit heretics, rather than the sexual deviants portrayed by Cohn, were instead "closely related to the orthodox mystical movement of the later Middle Ages." 58 His reinterpretation of primary source material set him apart from previous scholarship and helped to establish a new trend in the study of medieval heresy, one that critically examines the rationale behind inquisitorial sources before utilizing them in the study of heresy.

\footnotetext{
55 Lerner, Heresy of the Free Spirit, 3.

56 Ibid., 4.

57 Ibid., 6. 58 Ibid., 3.
} 
R.I. Moore, building upon numerous earlier studies and culminating in his 2014 monograph, utilizes a critical examination and contextualization of primary sources on heresy in order to attempt a more revisionist approach to the subject matter. He asserts that within the last twenty years historians have more critically examined the primary sources, questioning "their relationships to one another, the understanding, aims and motives of their authors, and in some cases their authenticity." 59 The result of this reassessment, he states, is that the "traditional story of 'medieval heresy' in which 'the Cathars' played a starring role" has been largely dismantled. Moore's goal is to retell the story of medieval heresy based upon a careful contextualization and assessment of the source material. Thus, he bases his book on a "pedantically painstaking text-by-text examination of each reported episode."60 As a result of this analysis, Moore questions whether organized groups of heretics that consciously challenged Catholic doctrines ever actually existed except in the minds of the inquisitors. Instead, he looks for political motivation or other alternative explanations behind accusations of heresy. This more recent work on medieval heresy, while not universally accepted by historians, presents an example of scholarship that questions all accusations of heresy through careful re-examination of primary source evidence and represents the other end of the historiography spectrum from Cohn.

\footnotetext{
59 R.I. Moore, War on Heresy: Faith and Power in Medieval Europe (Cumberland: Harvard University Press, 2012), 333. 60 lbid.
} 
Mark Pegg, writing in 2008, goes even further in his revisionist approach. He asserts provocatively in the introduction to his work that "More than a century of scholarship on both the Albigensian Crusade and heresy hasn't been merely vaguely mistaken, or somewhat misguided, it has been breathtakingly wrong." 61 Pegg argues that the "Cathars" described in historical scholarship, as well as popular culture, did not exist. Instead, he describes the tendencies of eleventhcentury intellectuals to conceptualize heresy as an unchanging, evil force that could be traced through time and space. ${ }^{62}$ He contends that the existence of heresy was necessary for an "eschatological vision," which was an essential element of this particular conception of Christianity. ${ }^{63}$ It was this world view that caused inquisitors to transform the faith of the "good men and women" into a treacherous heresy that necessitated a bloody crusade to eradicate it. Pegg reexamines the primary sources on the Albigensian Crusade through this lens in order to demonstrate his point. While not all historians completely agree with Pegg's conclusions, his book provides an important example of the benefits of contextualizing primary source material on heresy within the intellectual framework of the period in which they were written.

Given the debate surrounding the existence of heresy in medieval Europe, extreme caution is required when analyzing sources, especially inquisitorial

\footnotetext{
61 Mark Gregory Pegg, A Most Holy War: The Albigensian Crusade and the Battle for Christendom (Oxford: Oxford University Press, 2008), $x$.

62 Ibid., 41.

63 lbid.
} 
sources, as evidence of heretical activity. Due to the lack of source material to corroborate the existence of the Swabian heretics examined by Albertus Magnus in the Compilatio, I have chosen not to speculate on whether these people existed or on what they may or may not have believed. Instead, I will focus on the author's response to statements set forth in the document. While we lack sufficient information to analyze the heretical beliefs, Albertus has left ample clues in the document to allow us to critically examine his thought process and belief system in responding to their alleged ideas. This approach has been taken by many modern scholars in recent years when analyzing inquisitorial documents.

One example of this approach is the 1997 work of James Given. Given draws on inquisitorial records from heresy trials to attempt to better understand the lives of the lower classes. He analyzes the records in order to understand how "a medieval governing institution interacted with the people it sought to control."64 Given's stated intention is to critically examine these records in order to discern the thoughts and feelings of non-literate, medieval people. Given, therefore, critically examines inquisitorial sources in order to understand medieval governance, and not to gauge the extent of heretical activity.

Similarly, John Arnold also dedicates his 2001 analysis of inquisitorial records to better understanding the subjects of the inquisitorial trials. His book attempts to establish an ethical methodology with which to read inquisitorial 
confessions. This method utilizes Foucault's theories of power and discourse in order to discern the voices of the accused through the language of power of their inquisitors. ${ }^{65}$ His stated intention is to "engage with the voices of the deponents who were bound into the discourses of heresy and its repression."66 In order to accomplish this, Arnold attempts to find a way to address "the dialectical relationship between inquisitor and deponent," which he does by analyzing the effects of power within the sources. ${ }^{67}$ Arnold utilizes this method in order to allow the confessors to tell their own stories, which forms the culmination of his work. Arnold's work thus provides a valuable critique of previous historians who accepted inquisitorial statements at face value.

Many scholars argue that the inquisitorial records tell historians less about the supposed heretics than about the world view of those involved in its suppression. For example, Karen Sullivan, writing in 2011, chooses to analyze inquisitorial records, not to ascertain heretical practice, but in order to attempt to understand the inquisitors as literary subjects. ${ }^{68}$ Sullivan advocates comparing texts of inquisitors in order to better understand the individuals who wrote them. 69 She argues that the inquisitors can be understood as more than merely subjects

\footnotetext{
65 John Arnold, Inquisition and Power: Catharism and the Confessing Subject in Medieval Languedoc (Philadelphia: University of Pennsylvania Press, 2001), 3.

66 Ibid., 13.

67 Ibid., 8.

68 Karen Sullivan, The Inner Lives of Medieval Inquisitors (Chicago: The University of Chicago Press, 2011), 3.

69 Ibid., 22.
} 
of historical circumstance, but as agents in their own right. ${ }^{70}$ She sets out to examine them through their depictions in anti-heretical literature. Sullivan also attempts to understand what motivated inquisitors to persecute heretics. Finally, Christine Ames, in her 2014 book on the Dominican friars' response to heresy, acknowledges the scholastic debate surrounding the existence of heresy, but does not choose to participate in it. Instead, she analyzes the friars' response to heresy, without assessing whether the threat of heresy was legitimate. She discusses how recent scholars have challenged whether heresy actually existed 'independent of inquisitors' schematic or fanatical constructions of it." ${ }^{71}$ She contends that inquisitors constructed "cohesive categories of 'heresy,"' which could then be "imposed upon an individual's testimony" during an interrogation. ${ }^{72}$ These categories were developed from a combination of early church history and inquisitorial literature and frequently referenced early church heresies like Manichaeism. ${ }^{73}$ Rather than engage with this debate, however, she chooses to focus her work on how inquisitors utilized Christianity in order to justify the interrogation and punishment of perceived heretics. ${ }^{74}$ She chooses to analyze her sources through the lens of the inquisitors themselves. Therefore,

\footnotetext{
70 lbid., 15.

71 Christine Caldwell Ames, Righteous Persecution: Inquisition, Dominicans, and Christianity in the Middle Ages (Philadelphia: University of Pennsylvania Press, 2011), 9.

72 lbid.

73 lbid.

74 Ibid., 3.
} 
she accepts how they defined heresy, not as evidence of actual religious deviance, but as evidence of what the inquisitors considered to be heretical.

I have chosen to form my own analysis of Albertus Magnus' Compilatio using a methodology similar to that of Christine Ames and Karen Sullivan. While I acknowledge the debate surrounding the existence of distinct heretical sects, my analysis will focus instead on how Albertus himself perceived heretics and heterodoxy. I will examine how Albertus understands and classifies the errors of the supposed heretics and what religious and societal factors influenced his denunciation of their stated beliefs. While medieval heresy has been studied extensively, the manner in which scholars treat the sources has changed significantly over the last few decades. Consequently, many sources require new analysis which takes current scholarship into consideration. I will analyze this document in a manner consistent with the more recent trends in the scholarship. From this perspective, anti-heretical literature provides a more accurate picture of the authors themselves rather than the beliefs and practices of those they accused of heresy. The Compilatio has received little scholarly attention, and even less that analyzes the document from the perspective of Albertus. This work aims to rectify this omission and contribute to the recent scholarship analyzing the fight against heresy in the Middle Ages. 


\section{Chapter 1: The struggle to combat heresy}

The thirteenth century, when the Compilatio was composed, witnessed significant changes and events that markedly altered the Catholic Church in Europe. Institutional reformations in the eleventh and twelfth centuries had led many medieval people to take a more active role in their own faith. Many lay people, including women, following the apostolic model, formed semi-religious communities dedicated to a life of mendicancy, preaching, and poverty. Lay practitioners, both inside and outside of these communities, sometimes came into conflict with the established Church. The Church sought control over this outpouring of faith - sometimes by bringing practitioners into the Church and sometimes by declaring them heretics. The Dominican and Franciscan orders were both dedicated to the ideals of an apostolic faith, and were officially sanctioned by the Church. Their commitment to poverty as well as preaching made these orders invaluable tools to the papacy in its fight against heresy. Franciscan and Dominican inquisitors worked to combat heresy across Europe, producing a significant amount of anti-heretical literature of which the Compilatio is a part. In order to understand the document, it is therefore necessary to examine the period in which it was composed.

Social and economic changes in the thirteenth century, particularly in urban areas, considerably influenced religious practices. While thirteenthcentury Europe remained primarily a rural society, the population of the cities 
increased rapidly, largely due to migration from rural areas. ${ }^{75}$ Unable to support themselves in their villages, migrants moved to larger cities to find work. Many made their livings using the relatively recent feature of wage labor, which was supported by the increasing commercialization and monetization of urban society including the initial formation of rudimentary banks. ${ }^{76}$ Many less fortunate migrants, on the other hand, had to resort to begging. Sharon Farmer, in her study of the poor in Paris, describes crowds of beggars in the city's streets. ${ }^{77}$ She estimated that about half the population of Paris during this period consisted of laboring and non-laboring poor. ${ }^{78}$ For the more fortunate, guilds dedicated to specific industries flourished across European cities, and increasing trade opportunities expanded the merchant class. ${ }^{79}$

The growth of cities increased contact with "undesirable" groups of people such as Muslims, Jews, lepers, and prostitutes. ${ }^{80}$ Often these groups were required to identify themselves with distinctive clothing or badges. ${ }^{81}$ Steven Epstein, in A New Cambridge Medieval History, argues that the densely populated urban areas brought religious differences into conflict and created

\footnotetext{
75 Steven A. Epstein, "Urban Society," in The New Cambridge Medieval History, Vol. 5 c. 1198-1300, ed. David Abulafia (Cambridge: Cambridge University Press, 1999), 27-29.

76 lbid., 31.

77 Sharon Farmer, Surviving Poverty in Medieval Paris: Gender, Ideology, and the Daily Lives of the Poor (Ithaca: Cornell University Press, 2002), 34.

78 Ibid.

79 Epstein, “Urban Society”, 32.

80 lbid., 30.

81 Ibid., 30.
} 
animosities in the workplace which led to social intolerance. ${ }^{82}$ Additionally, cities, with their wealth and large populations, created opportunity for more experimental religious ideas. The Franciscan and Dominican Orders were active in the cities, as well as groups of lay people called beguines and beghards. The faith of these mendicant friars can be seen to present a protest to the increasing wealth of European cities as well as the wealth of the clergy. ${ }^{83}$ Francis of Assisi himself came from a wealthy merchant family before renouncing worldly possessions and forming the Franciscan order. The religious changes in the thirteenth century thus can only be understood against the backdrop of rapid social and urban change.

The significant religious changes that transpired during the thirteenth century derived from the reformations that began in the eleventh and twelfth centuries. Giles Constable argues that the "changes in religious attitudes and institutions" during the twelfth century "justify using the term reformation." 84 Constable contends that during the first half of the twelfth century, there was a common concern, centered around the ideal of personal perfection that led to the desire to monasticize the entire world. ${ }^{85}$ The spread of monastic ideals to the larger population changed the position of monks within society in several different ways. First, there was a general impression among much of the population that

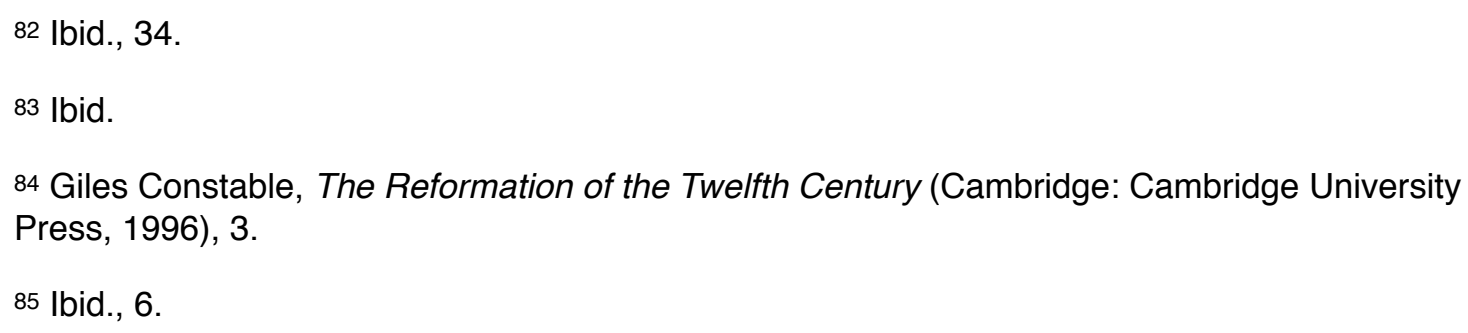


monks were not living up to the ideals of their own institutions. Many accusations were lodged against them of "hypocrisy, idleness, selfishness, avarice, lust, and worldly ambition." ${ }^{6}$ Reformers, worried about the effect of worldly society upon monks' spirituality, advocated for monastic institutions to cut their ties with secular society and withdraw from the world. ${ }^{87}$ Second, the spread of monastic ideals to the populace led to an increase in individual religious responsibility. ${ }^{88}$ For example, the attainment of salvation shifted from being viewed as a communal task to be accomplished with the assistance of the monasteries to a personal journey accomplished by the individual practitioner alone. This deprived the monasteries of their larger social purpose as the spiritual intermediaries for the larger population. 89 These changes by no means destroyed the institution of monasticism, which was able to adapt and survive. However, it did significantly alter medieval Christianity. Constable argues that following the twelfth-century reformation, there was a significant number of Christians who felt that there were "other ways to heaven, which seemed to them more pleasing to God than that of monks."90 These changes allowed for the formation of other religious institutions and ways of life.

\footnotetext{
86 Ibid., 306.

87 Ibid., 302-3.

88 Ibid., 305.

89 lbid.

90 Ibid., 325.
} 
Following this twelfth-century reformation, many historians have noted an increase across Europe in lay piety evident. Herbert Grundmann contends that the monastic reforms "awakened" the population and inspired many to question whether the Church need be the only means for achieving Christian salvation. ${ }^{91}$ Instead, many Christians looked to the example of the apostles described in the Bible and modeled their own lives after this "apostolic standard."92 Instead of only following the teachings and traditions of the hierarchical Church, these devotees sought a personal commitment to Christ that formed a "religious way of life." Termed the vita apostolica, it was dedicated to following the example of the apostles. ${ }^{93}$ This ideology was centered around the "desire for voluntary, religious, or apostolic poverty described in the Acts of the Apostles."94 Devotees who had renounced their wealth frequently lived off the charity of others by begging, and mendicant preachers traveled around the countryside preaching to the laity in the vernacular.

This religious lifestyle contrasted with that of the Church and sometimes came into conflict with it. Walter Simons in his work on beguines argues that the ideal of apostolic poverty either "implicitly or explicitly" contrasted with Church practice. 95 This institutional Church was quite wealthy and was a significant land

\footnotetext{
91 Grundmann, Religious Movements in the Middle Ages, 7.

92 Ibid.

93 Ibid., 8.

94 Walter Simons, City of Ladies: Beguine Communities in the Medieval Low Countries, 1200-1565 (Philadelphia: University of Pennsylvania Press, 2003), 14. 95 Ibid.
} 
holder. Bishops, parish priests, and members of the lower clergy were all given an income from the Church. Even monks and nuns lived comfortably off of the sizable endowments that formed their monastic houses. ${ }^{96}$ Therefore, the choice of voluntary poverty raised questions regarding the integrity of those working within the hierarchical Church. ${ }^{97}$ Additionally, Church services were conducted in Latin, as opposed to the vernacular utilized by the wandering preachers. This made the services less accessible to uneducated members of the laity. Further, some who followed the apostolic life openly criticized members of the clergy for engaging in immoral practices. Simons argues that these tensions between the apostolic movement and the "clerical establishment" led to conflict and some of the first accusations of "popular heresy." 98 Indeed, the Church did prosecute as heretics some of those who practiced an apostolic way of life.

Of the many individuals who, inspired by the example of the apostles, wished to dedicate their life to Christ, a large proportion were women. The Catholic Church simply did not have sufficient room for all of these women to join monastic houses, nor could all who wished to join pay the required donation for admittance. ${ }^{99}$ Some of these women, termed beguines, formed semi-monastic communities frequently on the outskirts of urban areas, particularly in northwestern Europe. Simons states that these communities allowed single

\footnotetext{
96 Ibid.

97 Ibid.

$98 \mathrm{lbid}$.

99 Simons, $x$.
} 
women of any age the "opportunity to lead a religious life of contemplation and prayer" without withdrawing completely from the temporal world.100 Men also formed semi-monastic communities of beghards, although these were not as common as the female communities. The beguines and beghards came into frequent conflict with religious authorities. ${ }^{101}$ They were subject to condemnation both from within and outside of the official Church. Lerner argues that they were accused of being too pious, while at the same time accused of hypocrisy. ${ }^{102}$ The Catholic Church vacillated in its response to the beguine communities, with official condemnation not occurring until 1274 during the Second Council of Lyon. Many of the heretical errors described in the Compilatio specifically mention women, which follows this trend of an outpouring of female spirituality.

Many of those who lived in the beguine communities or practiced the vita apostolica experienced mystical episodes or espoused mystical theology. ${ }^{103}$ The topic of mysticism has been much discussed and debated by medieval historians. A definition of mysticism by Bernard McGinn, one of the preeminent scholars on the subject, defines it as a "special consciousness of the presence of God that by definition exceeds description and results in a transformation of the subject who receives it."104 Barbara Newman, another scholar of mysticism,

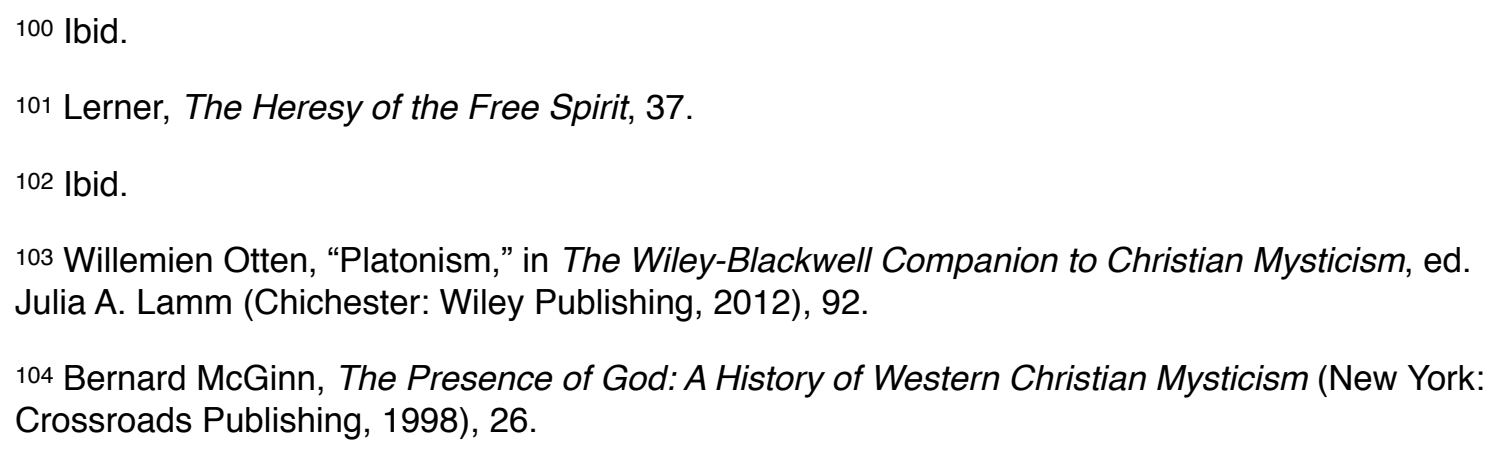


defines it as a "quest for experiential union with God," which "seeks to transcend all categories of human thought, including sex and gender."105 Mysticism generally involves personal, direct interactions between the practitioner and God. Church authorities often viewed mystics with suspicion. While not all mystics were persecuted as heretics, some certainly were when they were deemed to present a threat to Church authority or to have strayed beyond the bounds of orthodoxy.

Church officials were perhaps most worried about a tendency of some mystics towards antinomianism, the "belief that laws no longer apply to a soul that has attained perfection."106 This viewpoint was particularly threatening to the Church because it would make ecclesiastical and moral law obsolete for those who achieved divine salvation. The Catholic Church was so preoccupied with mysticism, and antinomianism in particular, that during the council of Vienne in 1311-1313 the council issued a decree known as Ad nostrum, which condemned many purported spiritual errors of an "abominable sect of wicked men ... and of faithless women."107 Antinomianism was chief among these reported errors. Ad nostrum claims to describe a certain sect of heretics, termed the Free Spirits, who possessed defined teachings. This assertion was once accepted by some historians, but more recently scholars have come to the conclusion that the

\footnotetext{
105 Barbara Newman, "Gender," in The Wiley-Blackwell Companion to Christian Mysticism, ed. Julia A. Lamm (Chichester: Wiley Publishing, 2012), 69.

106 J. Patrick Hornbeck, "Heresy," The Wiley-Blackwell Companion to Christian Mysticism, ed. Julia A. Lamm (Chichester: Wiley Publishing, 2012), 123.

107 lbid.
} 
Free Spirits could not be classified as an organized sect or movement, but rather constituted a few scattered individuals or small groups. ${ }^{108}$ Most historians now emphasize their doctrinal similarity with orthodox medieval mysticism.

The debate surrounding the Free Spirit heresy is of particular relevance to this thesis because some medieval, and a few contemporary, writers have argued that the heresy documented by Albertus Magnus in the Swabian Ries actually marked the origin of the Free Spirit heresy. This link is reflected in the full title of the document - Compilatio de Novu Spiritu. Indeed, Michael Bailey observes that Johannes Nider, a Dominican inquisitor who authored the Formicarius in the early fifteenth century, ascribes the origins of the Free Spirit heresy to Albertus Magnus' account of heresy in the Swabian Ries. ${ }^{109}$ Robert Lerner, in his discussion of the origins of heresy of the Free Spirit, contends that the heresy in the Swabian Ries "resembles[s] many later accounts of the FreeSpirit heresy so much that they may be regarded as typical."110 While he concedes that the heretics in the Swabian Ries "may not have directly influenced others who came later," he does contend that they "seem to have spoken the same language."111 Scholarly consensus that the Free Spirits did not constitute a united sect of heretics makes unlikely a definitive origin of the sect in the Swabian Ries. Grundmann's assertion that the origins of the Free Spirit heresy

108 lbid.

109 Bailey, Battling Demons, 56.

110 Lerner, Heresy of the Free Spirit, 14.

111 lbid. 
can be found in the "crisis in Christian life" evident in the thirteenth century, which led many Christians to "find new paths to higher religious perfection," forms a more accepted scholarly viewpoint. ${ }^{112}$ However, while the origin of the title of the Compilatio remains an open question, it speaks to the antinomian tendencies evident within the heretical statements it sets forth.

With the outpouring of support for the apostolic lifestyle, the Church had to develop an official response to deal with those practicing the faith outside the bounds of the Church. During the twelfth century, Grundmann contends, the Church was consistently averse to the entire religious movement. ${ }^{113}$ However, after Innocent III ascended to the papacy in 1198, the policy of the Church towards the apostolic movement began to change. Pope Innocent worked to provide an avenue for those practicing the apostolic life to join the Church. As long as these believers were willing to recognize church law and authority he allowed them a legitimate place within the hierarchical Church. ${ }^{114}$ Congruent with this policy, however, was a stricter approach towards combatting heresy.

The Lateran Council of 1215 helped to codify the Church's position towards heresy, and in so doing helped to better define Christianity. For example, it included a "detailed profession of the faith," which was used to test the orthodoxy of suspected heretics. ${ }^{115}$ The Fourth Lateran Council altered the

\footnotetext{
112 Grundmann, Religious Movements, 161.

113 Ibid., 5.

114 Ibid., 32.

115 Ibid., 187.
} 
manner in which heretics were condemned, moving away from ordeals of fire and water to a more refined definition of dogma which delineated orthodoxy from heterodoxy. ${ }^{116}$ It also established recommended measures for the Church to combat heresy, including a penal code for those who were condemned as heretics. ${ }^{117}$ Additionally, the Council strove to prevent unlicensed preaching by lay people as well as limit the formation of new orders. Grundmann argues that this suspension in the approval of new orders was in "unmistakable opposition to Innocent's earlier decisions and measures, and was an attempt to retain order in the Church" 118 If followed, this decision would have prevented the mendicant orders, including the Dominicans, from obtaining official recognition. ${ }^{119}$

Despite this fact, the Dominicans did obtain papal approval after, and the Franciscans just prior to, the Lateran Council giving a legitimate place in the Church to those who practiced the apostolic life. Dominic, with his patron Bishop Fulk of Toulouse, went to Rome shortly before the Fourth Lateran Council to seek endorsement for their foundling order from Pope Innocent III. While Innocent reportedly received them kindly, he was reluctant to give his support to Dominic's proposed order of preachers because that would take power away from the bishops. ${ }^{120}$ Shortly thereafter, the Lateran Council banned the creation of new

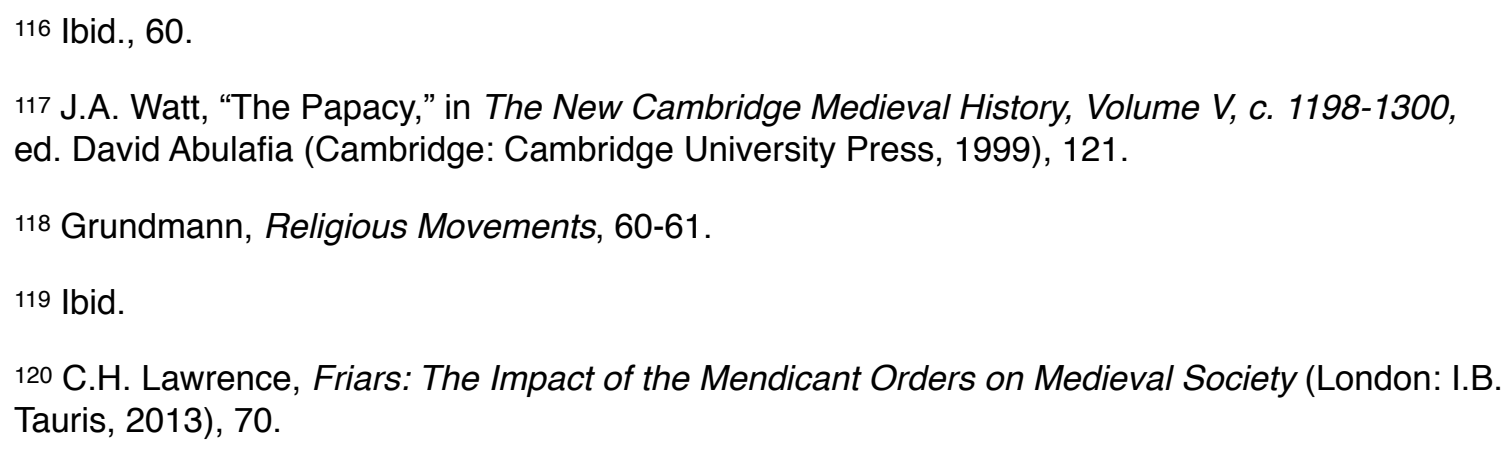


orders, so Dominic was forced to join his order with the Rule of St. Augustine. ${ }^{121}$ In 1216, Pope Honorius III confirmed Dominic's order. However, this papal recognition did not ratify any specific rule or organization. ${ }^{122}$ The Dominican Order, therefore, was allowed to develop its own organizational structure, which was officially considered merely a branch of the canons regular. ${ }^{123}$ However, this did grant them legitimacy and a place within the hierarchical church.

The Dominican Order, of which Albertus Magnus was a member, was defined by their adherence to the apostolic life. For the Dominicans, this meant living the life of an itinerant preacher, as well as their refusal to own any material goods beyond what was absolutely necessary for survival. ${ }^{124}$ They thus depended upon alms for their food and clothing. ${ }^{125}$ This ideal of apostolic poverty was central to the conception of the Dominican Order. As related by Jordan of Saxony, Dominic's chronicler, Dominic and his colleague Diego of Osma recognized the need for a monastic order formed around apostolic ideals while traveling through the Languedoc region of France. There, the good men and women, labeled and prosecuted as heretical Cathars, were well known for their austere lifestyle. Jordan of Saxony, one of the first leaders of the Dominicans, related that these religious people won converts due to their

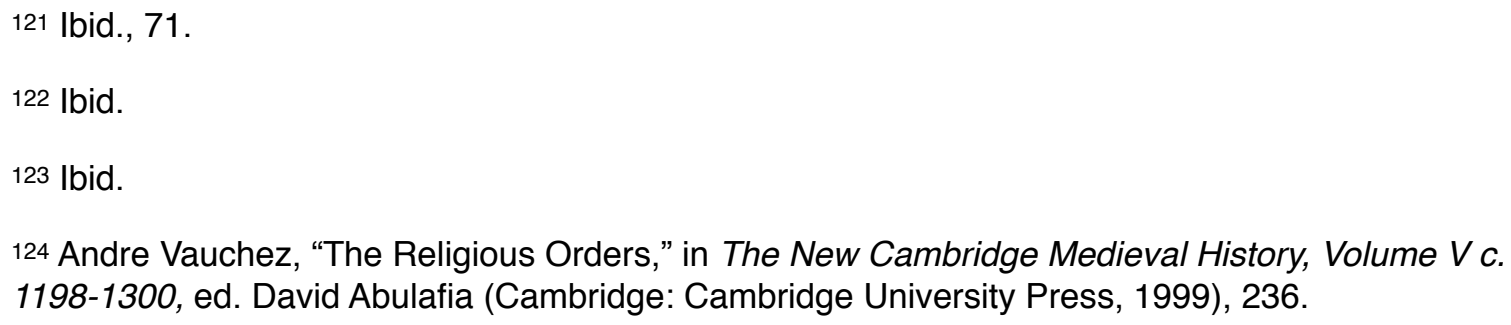


example of evangelical poverty. Therefore, in order to compete with the draw of the good men and women of the Languedoc, preachers would need to also live an austere lifestyle based on apostolic ideals. ${ }^{126}$ The Dominican Order formed around these ideals. Further, the Dominicans were dedicated to a preaching mission which sent members across Europe to preach the word of God. In order to prepare their members for this mission, the Dominicans were well-educated, especially with the skills needed for preaching. ${ }^{127}$ This preaching mission was endorsed by the papacy - Honorius III (1216-1227) provided them with papal letters in 1218 which commanded the clergy to "render them all possible assistance with their ministry of preaching."128 Therefore, both the apostolic life and the campaign against heresy were central to the formation of the Dominican Order and its religious identity.

These characteristics made the Dominican Order an ideal tool of the papacy in the fight against heresy. Herbert Grundmann contends that even prior to the formation of the mendicant orders, Pope Innocent thought to utilize "ecclesiastical preachers living in apostolic poverty" in order to combat the growing heretical threat. 129 These preachers, by adhering to the apostolic ideals themselves, would have better credibility with pious lay people who found themselves on the wrong side of orthodoxy. He further contends that it was not

\footnotetext{
126 Ibid.

127 lbid.

128 Ibid., 72.

129 Grundmann, Religious Movements, 46.
} 
just a method to combat heresy, but a way to integrate the religious movement into the Church. ${ }^{130}$

The mendicant orders were not just utilized by the papacy in its fight against heresy, but also in their crusades, especially after 1230 during the papacy of Gregory IX (1227-1241). Crusades were waged by popes in the thirteenth century for many reasons. Primarily, they were conducted to reclaim the Holy Land from the Muslims. However, popes also enacted crusades against pagans in Lithuania, Christian leaders who disobeyed papal authority, as well as heretics. ${ }^{131}$ The friars were frequently appointed as preachers in these crusades and were sent out to recruit crusaders and spread papal propaganda. ${ }^{132}$ Christoph Maier, in his work on this subject, argues that the Dominicans' diplomatic and preaching skills along with their dependability were some of the main characteristics that made the order valuable to the papacy. ${ }^{133}$ For this reason, popes chose the friars to send into the more difficult crusading locations. ${ }^{134}$ Maier argues that without the mendicant orders, Gregory IX would not have been able to carry out the various crusades that he waged during his papacy. ${ }^{135}$ These papal missions, however, tested the loyalty of the mendicant

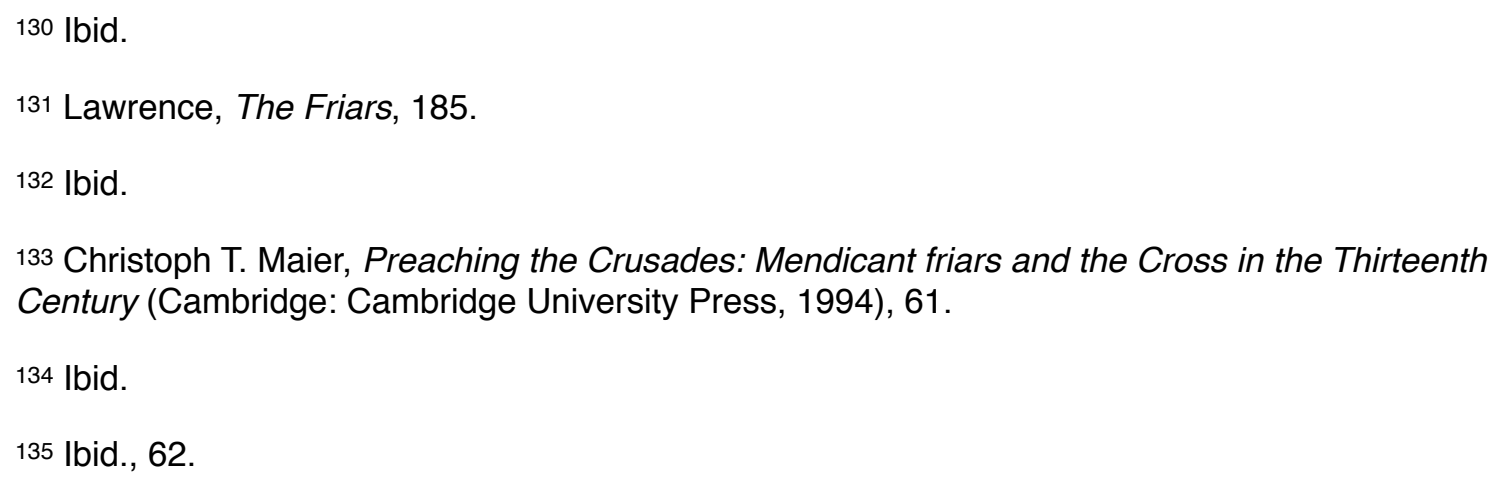


orders, as they were sometimes asked to carry out tasks that violated their vows of poverty as well as their aim of political neutrality. ${ }^{136}$

The Dominican Order was also utilized by the papacy in the inquisition against religious heterodoxy. Gregory IX established permanent courts to try heretics in the early 1230 s. Heresy trials were supervised by "specially appointed inquisitors," which were generally recruited from the Dominican Order. ${ }^{137}$ Christine Ames contends that the Dominicans were used not just because of their prominence in theology but because of their "foundational pastoral and apostolic vision."138 Similarly, Maier argues that the Dominicans were valuable in heresy trials because of their "theological training and their dialectical experience," which made them successful interrogators. ${ }^{139}$

Ames further argues that the inquisition coincided with the values of the Dominican order. She contends that it was part of the vision of the Dominican order to seek to "extend a monastic model to the laity."140 Specifically, Ames argues that the Dominicans sought a universal Christian community with God at its head. ${ }^{141}$ In this universal community, individuals would obey the will of God, practice chastity, work for the good of others, and continually investigate their

\footnotetext{
136 Lawrence, The Friars, 186.

137 Sullivan, The Inner Lives of Medieval Inquisitors, 7.

138 Ames, Righteous Persecution, 8.

139 Lawrence, The Friars, 190.

140 Ames, Righteous Persecution, 8.

141 lbid.
} 
souls to ensure proper dedication to God. ${ }^{142}$ The inquisition assisted in this pursuit because, she argues, the inquisition sought "total jurisdiction" for the church over the "subtlest details of the engagement between human and divine."143 For the Dominicans, then, the inquisition fulfilled Dominic's vision for the order, rather than the corrupted it. ${ }^{144}$ The Dominicans, therefore, were valuable assets to the inquisition because their order agreed with its fundamental aims.

During their fight against heresy, inquisitors, particularly Dominicans, amassed a considerable amount of literature on the heretical threat they faced, of which the Compilatio is a part. This literature existed in many different formats. There were canon law texts and papal bulls issued which dealt with the subject of heresy and how to combat it. Additionally, the inquisitors produced transcripts from inquisitorial trials, which included notes and commentary, as well as formulae for interrogations to assist other inquisitors during trials. ${ }^{145}$ The first known inquisitorial manual was written as early as $1248 .{ }^{146}$ Following this first simple manual, these resources became more sophisticated and included information on "inquisitorial theory" as well as detailed descriptions of the heretical threats the inquisitors faced. ${ }^{147}$ Much of this anti-heretical literature, like

142 Ibid.

$143 \mathrm{lbid}, 10$.

144 lbid, 8.

145 Ibid, 16.

146 Given, Inquisition and Medieval Society, 45.

147 Ames, Righteous Persecution, 17. 
the Compilatio discussed in this thesis, also describes heretical beliefs in order to refute them.

\section{Anti-heretical Literature}

Anti-heretical literature, despite being created across different regions and periods, demonstrates many similar themes and ideas. Edward Peters contends that the Dominican inquisitors formed a "separate profession ... of inquisitor" with "specialized literature based upon inquisitorial archives."148 This literature was based upon common source material, and new generations of inquisitors extensively utilized their predecessors' documents in the creation of their own. ${ }^{149}$ Wakefield, in a 1967 article, closely analyzes inquisitorial material to demonstrate the degree to which these authors borrowed from their predecessors. He contends that some treatises were formed almost entirely from "pre-existing documents."150 Malcolm Lambert contends that heretics were described by inquisitors with similar language which was then utilized by subsequent inquisitors. ${ }^{151}$ This produced some standard characteristics and categories of transgression that could be applied to accused heretics. ${ }^{152}$ Therefore, considerable anti-heretical literature was created from the thirteenth to the

\footnotetext{
148 Edward Peters, ed., Heresy and Authority in Medieval Europe: Documents in Translation (Philadelphia: University of Pennsylvania Press, 1980), 191.

149 Ames, Righteous Persecution, 17.

150 Walter L. Wakefield, "Notes on Some Antiheretical Writings of the Thirteenth Century," Franciscan Studies 27 (1967): 320.

151 Lambert, Medieval Heresy, 4.

152 lbid.
} 
sixteenth century which utilized common source material and demonstrated similar themes.

James Given, in his work on the inquisition, describes how changes in documentary technology during this period helped inquisitors develop and retain this body of literature. Given contends that most European governments archived their important documents by the thirteenth century. ${ }^{153}$ He argues that while the inquisitors were not unique in their use of archives, they were able to utilize them more effectively in order to "exert power in a more concentrated and efficient way." 154 He describes how inquisitors developed tools to expedite finding information, such as indexes and chapter headings. Further, inquisitors actively re-copied anti-heretical literature to proliferate the materials. ${ }^{155}$ Given contends that inquisitors' record-keeping and archiving greatly contributed to their success and were, in fact, a "necessary part of the inquisitors' investigative technology."156 The survival of the "Compilato" is a testament to this archival technology.

Within this body of anti-heretical literature, the threat of heresy was characterized by the inquisitors in several different ways. How heresy was portrayed by the inquisitors reveals how they interpreted the threat and helps us

\footnotetext{
153 James B. Given, Inquisition and Medieval Society (Ithaca: Cornell University Press, 1997), 25. 154 Ibid., 26.

155 Ibid., 35.

$156 \mathrm{lbid}, 39$.
} 
understand their response to it. Many scholars of medieval heresy have discussed these different representations.

One common representation utilized by both friars and the Catholic Church was to describe heresy as an insidious disease, spreading through the populace. Wakefield and Evans, in their compilation of primary source documentation on heresy, argue that heresy was considered a "deadly contamination" which necessitated "constant vigilance against infection." 157 They further argue that is was conceived as one of the "worst offenses against Christian society."158 R.I. Moore, in his The Formation of a Persecuting Society, argues that heresy was linked to the disease of leprosy in the writings of twelfthcentury writers. These men described heresy as "running far and wide" and "infecting the limbs of Christ."159 He further describes how heresy was viewed as an infection that required fire in order to be eradicated. 160 He cites examples where heretics' homes and belongings were burned so as to stop the spread of the infection. ${ }^{161}$ Christine Ames, similarly, cites sermons by Dominican preachers which argued that heresy was particularly threatening because it "led others into wicked belief," thereby infecting them like a disease. ${ }^{162}$ Further, these sermons

\footnotetext{
157 Walter L. Wakefield and Austin P. Evans, eds., Heresies of the High Middle Ages (New York: Columbia University Press, 1969), 2.

158 Ibid.

159 R.I. Moore, The Formation of a Persecuting Society: Authority and Deviance in Western Europe, 950-1250, (Malden, MA: Blackwell Publishing, 2007), 61.

$160 \mathrm{lbid}, 60$.

161 lbid.

162 Ames, Righteous Persecution, 39.
} 
describe heresy as particularly threatening because of the difficulty in detecting it, as it "conceals itself under the likeness of good."163 These sermons even attempted to define heresy as "obstinate spiritual sabotage" which sought to destroy the entire Church. ${ }^{164}$

Some historians also describe how medieval writers conceived of heretics as agents of the devil. R.I. Moore points to a "rhetoric of demonization" which describes heretics, as well as other persecuted groups, as engendered by the devil or at least in direct communication with him. ${ }^{165}$ Writing in 1987, Moore links the persecution of heretics to a more general zeal for persecution in European society. ${ }^{166} \mathrm{He}$ asserts that during the eleventh, twelfth, and thirteenth centuries, a "myth was constructed, upon whatever foundation of reality, by an act of collective imagination" surrounding Jews, lepers, and heretics. ${ }^{167}$ By depicting these groups as agents of the devil, they were portrayed as enemies of God and of a Christian community. ${ }^{168}$

Karen Sullivan also argues that zealous inquisitors conceived of heretics as "minion[s] of the devil."169 She further contends that these more fervent inquisitors conceived heretics as a threatening "other," which was "sharply

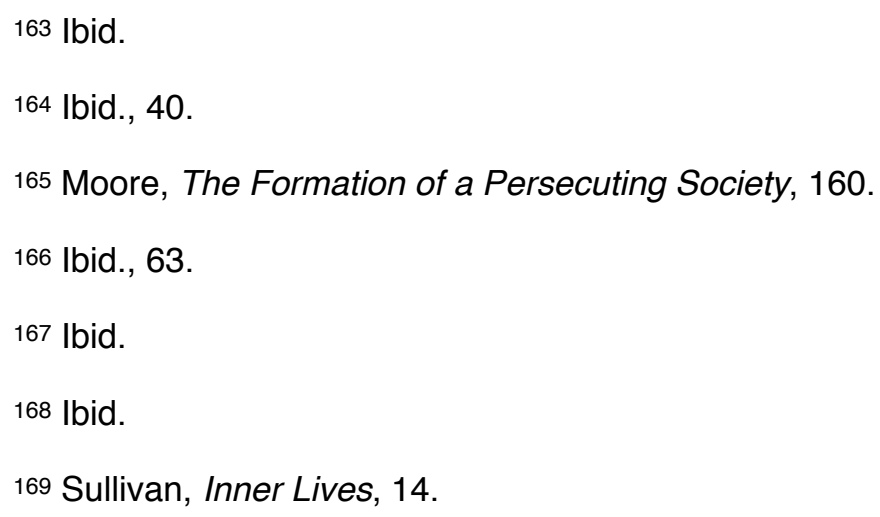


distinguished from the self." 170 For these men, heretics were "forerunner[s] of the Antichrist," who preceded the devil's arrival on earth. ${ }^{171}$ Under this conception of heresy, Sullivan contends that these inquisitors pursued heretics out of love. 172 However, she qualifies this statement to say that the inquisitors might understand this love more as "charity or zeal," and zeal may more often "look like hate" than love. ${ }^{173}$ She argues that during the mid-twelfth to mid-fourteenth century, during which time the Compilatio was written, the Church more often emphasized the need to pursue heretics with zeal "on behalf of the common people." 174 If the heretics were indeed thought to be agents of the devil, then pursuing them could be an act of sincere religious devotion for the good of the entire Christian community.

By contrast, the Dominicans' conceived of their preaching and inquisitorial pursuits as the work of Christ, while those who deviated from the Catholic Church's dogma were inspired by the devil. ${ }^{175}$ Christine Ames cites sermons by Dominican preachers which discuss the threat from heresy. Among these sermons, many of them utilize the parable of wolves dressed in sheep's clothing (Matthew 7:15) to describe the danger of heresy to the Christian population. In this example, the wolves are the heretics, while the sheep are the good

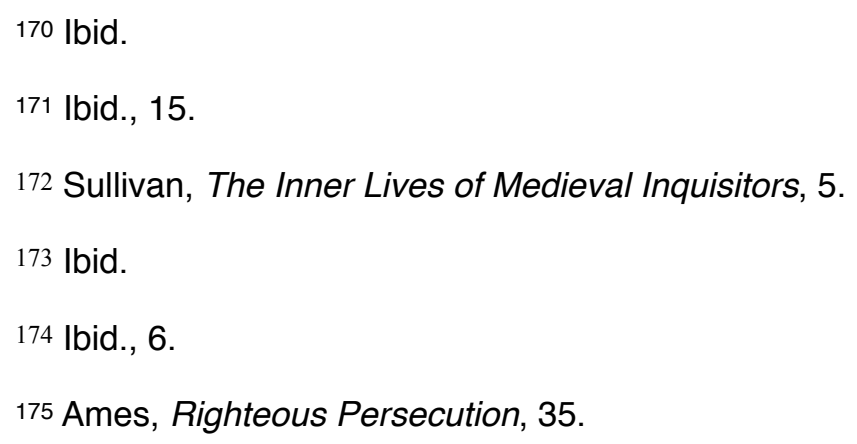


Christians who are being deceived by the wolves. For the writers and preachers described by these historians, inquisitors had a Christian duty to work against these devil-inspired heretics who presented a real danger to the Christian community.

Many historians, when analyzing inquisitorial sources, characterize heresy as threatening to the Church's power and its monopoly on salvation. Christine Ames, for example, argues that the goal of sermons preached against heresy was to assert that "no one could be truly pious who deviated from the custom and faith of the Roman Church."176 Ames, however, contends that the Dominican friars were sincere in their Christian vision expressed during the pursuit of heretics. ${ }^{177}$ She asserts that they were genuinely attempting to extend a monastic ideal to the laity which would emphasize "investigation of the soul, vigilance about others, chastening of the body, cultivation of the will to obedience and awareness of a surpassing, universal, timeless community with God at its head."178 She contends that inquisitors often focused on minor heretical infractions, such as sheltering a heretic or expressing the belief that heretics were pious because they sought to claim the Church's complete authority over all aspects of interaction between human and divine. ${ }^{179}$ This coincided with the Dominican ambition to extend a monastic model to the laity, but it also served to

\footnotetext{
176 Ames, Righteous Persecution, 41.

177 Ibid., 10.

178 lbid., 8.

179 lbid, 9.
} 
increase Church power over society. R.I. Moore takes a slightly more extreme viewpoint. He contends that many accusations of heresy were more concerned with not believing in the power of the church, rather than not believing in God. ${ }^{180}$ Moore further argues that the persecution of heretics helped to define Church doctrine by eliminating from the Christian community those whose "stubborn insistence on avowing particular doctrines, adhering to particular practices or following particular leaders seemed in one way or another to frustrate the ideals or obstruct the ambitions of secular or ecclesiastical power."181 For Moore, the persecution of heresy served only to empower the church and was not a sincere expression of faith.

Albertus Magnus' Compilatio follows many of the trends in anti-heretical literature discussed above. His refutation of the heretical statements of the accused heretics in the Swabian Ries draws a clear distinction between orthodox views supported by the Bible, Augustine, or Gregory the Great and the heretical beliefs which he denigrates as "blasphemy" and "folly." Additionally, many of the heretical statements refuted in the Compilatio threatened the power of the Church, allowing as they did for salvation outside the official Church. For example, statements in the document assert that pious men need not confess their sins to a priest, that "man united to God does not have to revere the saints," and that pious men need not celebrate the holidays which the Church

\footnotetext{
180 Moore, The War on Heresy, 329.

181 Ibid., 330.
} 
celebrates. ${ }^{182}$ Achieving salvation outside the Church is a significant theme among the heretical statements presented in the Compilatio, and supports historians Christine Ames' and R.I. Moore's arguments that the Dominican inquisitorial literature served to consolidate the power of the Church in medieval society.

182 Albertus Magnus, "Compilatio," 462: "quod homo unitus deo non habeat sanctos revereri". 


\section{Chapter 2: Inquisitorial Tactics}

Dominican and Franciscan friars, including Albertus Magnus, utilized several common tactics in their campaign against heresy. Many scholars have discussed these strategies in their works on heretical inquisitions. In order to establish credibility, it was typical for inquisitors to cite the Bible to support their arguments when condemning heresy. Spiritual authorities like Gregory the Great and St. Augustine were also frequently quoted. Additionally, many inquisitors utilized accusations of sexual immorality to discredit those accused of heresy, even when there was little evidence of sexual impropriety. James Given contends that because the Church did not always comprehend the exact beliefs of supposed heretics, Church officials would link these "contemporary dissidents" with "those found in the pages of the Church fathers."183 Thus, many thirteenthcentury heretics were identified with such early Church heretics as the Manichaeans and the Donatists. Ames and Arnold both emphasize that a crucial element of inquisitorial works was to establish "categories of transgression," to which the inquisitors would then assign the accused heretics "according to an assessment of their actions and words."184 In this way, categories constructed in inquisitorial literature could be imposed upon the accused's testimony so that the contemporary heretics could be linked with older heresies. 185

183 Given, Inner Lives of Medieval Inquisitors, 13.

184 Arnold, Inquisition and Power: Catharism, 9. Ames, Righteous Persecution, 8. 185 Ibid. 
Making allegations of sexual immorality against accused heretics was a particularly common method utilized by inquisitors. As Christine Ames contends, inquisitors needed to "dislodge the heresy's spiritual credibility with the laity," and one method they used to accomplish this was lurid accounts of sexual depravity. ${ }^{186}$ Similarly, Robert Lerner critically examines accusations of sexual immorality against the Free Spirits, and concludes that heretics in the thirteenth century were "simply assumed to be immoralists."187 He cites numerous examples of similar language used to describe the sexual liberties taken by many different accused heretics. However, allegations of sexual immorality were not limited to the thirteenth century. Augustine, in his work Concerning Heresies, depicts the sexual depravities of the Manichaeans. He cites the testimonies of a twelve-year-old girl and a woman who was "some kind of Manichaean nun," who both claimed to have been violated during a religious rite. ${ }^{188}$

Albertus Magnus similarly utilizes this trope of inquisitorial literature. He details numerous statements from the accused heretics of the Swabian Ries that express sexual immorality. For instance, he relates that the heretics believe that "what is done under the belt by good men is not sin." 189 The document also relates that "a girl is permitted to have sex without stain." 190 These assertions of

186 Ibid., 38.

187 Lerner, The Heresy of the Free Spirit, 22.

188 St. Augustine, "On Manichaeism," in Heresy and Authority in Medieval Europe, ed. Edward Peters (Philadelphia: University of Pennsylvania, 1980), 35.

189 Ibid., 467: "quod fit sub cingulo a bonis non sit peccatum."

190 Ibid., 466: "pueram ex licit concubitu pariens sine macula." 
sexual immorality serve to discredit the piety of the heretics to the readers of the Compilatio. Robert Lerner discusses these statements in more detail. He contends that the assertion that what is done "under the belt" is not a sin appears in many medieval depictions of "completely disparate heresies" in Southern France, Italy, Germany, and Moravia. ${ }^{191}$ Lerner explains that while this description has been used in many accounts of heresy, he was unable to locate the original description in the patristic texts. ${ }^{192}$ This supports the assertion that allegations of the sexual liberties of heretics were utilized by inquisitors in order to discredit the accused heretics, and likely do not describe actual instances of immorality.

In addition to accusations of sexual immorality, Albertus Magnus also links the contemporary heretics in the Swabian Ries with ancient heresies. While this was a common strategy utilized by other inquisitors, Albertus Magnus uses ancient heresies somewhat differently in this document. Many other inquisitors described contemporary heretics as Manichaean or Arian. Use of these early church heresies as a synonym for heresy lent legitimacy to their accusations. Albertus Magnus, however, utilizes ancient heresies much more extensively. Of the ninety-seven heretical statements listed, Albertus compares roughly twothirds (sixty-five statements) to fifteen different ancient heresies. Some of these are well known, such as the Manichaean and Pelagian heresies, while others are more obscure, such as the Elyoriste and the Ordevi heresies. How Albertus

\footnotetext{
191 Lerner, The Heresy of the Free Spirit, 20.

192 lbid.
} 
ascribes these ancient heresies to the heretical statements is generally dictated by a thematic commonality. As such, the ancient heresies serve as a cursory system of categorization throughout the document. An analysis of how Albertus employs this system reveals how he viewed thirteenth-century heresy and what elements of this heresy concerned him.

The ancient heresy most frequently referenced by Albertus Magnus in the Compilatio is Pelagianism. Albertus ascribes thirty-seven different statements to Pelagius and Pelagianism, which pertain to many varied beliefs on such topics as sexuality, sin, fasting, prayer, and the cult of the saints. These varied statements have a thematic commonality in that they emphasize humans' ability to achieve salvation through their own means. Most of the statements by the accused heretics that Albertus attributes to Pelagianism seem to evidence a belief in the goodness, even the sanctity, of human nature.

Pelagius lived from c.355 to c.420. He and St. Augustine disagreed on many elements of Christian theology, particularly concerning original sin. Pelagius argued that Adam's actions left his descendants with the propensity to sin, not with the legacy of original $\sin .{ }^{193} \operatorname{Sin}$, Pelagius argued, requires a voluntary action; it has not been merely inherited. Under this theory, infants were baptized not to save them from sin, but to bring them into the life of the Church. ${ }^{194}$ Pelagius' teachings place considerable faith in the goodness of

\footnotetext{
193 lan A. McFarland, The Cambridge Dictionary of Christian Theology (Cambridge: Cambridge University Press, 2011), 377.

194 Ibid.
} 
human nature. Specifically, he trusts in human beings' ability to find God through virtue and free will. His conception of Christianity relies, therefore, more on tangible actions than merely on grace. ${ }^{195}$ However, Pelagius was condemned as heretic at the Council of Carthage in 418, which relegated his views on free will to the realm of heterodoxy.

Albertus references Augustine's writings throughout the Compilatio, and his conception of Pelagius seems to rely heavily upon Augustine's descriptions. Augustine describes Pelagians as "enemies of the grace of God, and all it implies."196 Specifically, Augustine denounces Pelagius for the view that "it is possible to attain righteousness and eternal life in some other way than by the sacrament of Christ."197 Augustine argues that if a person can achieve salvation through "natural law and the choice of will," as Pelagius asserts, then Christ will have died in vain, as his sacrifice would be unnecessary. ${ }^{198}$ As Dominic Keech elucidates in his work on Augustine, if Pelagius teaches that humans can achieve salvation through freedom of will, then prayer and the Church are rendered superfluous. ${ }^{199}$ Keech explains that Augustine, in contrast, believed that if humans understood their sinful nature through the Law, then they could "call on

\footnotetext{
195 Ibid., 378.

196 Dominic Keech, The Anti-Pelagian Christology of Augustine of Hippo, 396-430 (Oxford: Oxford University Press, 2012), 35.

197 St. Augustine, "On Nature and Grace," in Selected Writings on Grace and Pelagianism, trans. Roland Teske (New York: New City Press, 2011), 322.

198 Ibid., 324.

199 Keech, The Anti-Pelagian Christology of Augustine, 35.
} 
the grace of Christ for aid" to save them from their sins.200 Consequently, Pelagius came to be associated with the belief that humans can achieve salvation on their own, without the aid of the Church. Isidore of Seville, writing in the seventh century, describes Pelagius and Pelagians in similar terms. He states that they "put free will before divine grace, saying that will is sufficient to fulfill divine commands."201

Albertus Magnus' conception of Pelagianism seems to follow the prevailing view that Pelagius' ideas would render the Church unnecessary. The statements Albertus compares to Pelagianism demonstrate a disregard for Church laws or practices. One alleged heretical statement contends that "man advances so much that he does not require a priest."202 Another asserts that "one ought not seek the council of learned men either concerning devotion or concerning other things."203 Albertus contends that this statement is the "same presumption of Pelagius, who placed his own perception for judgement in command of scripture." ${ }^{204} \mathrm{~A}$ third avows that man is able to arrive at a level of spirituality where "he is not required to revere the saints."205 These statements

200 lbid., 16.

201 Isidore of Seville, The Etymologies of Isidore of Seville, ed. Stephen A. Barney, et al. (Cambridge: Cambridge University Press, 2010), 178.

202 Albertus Magnus, "Compilatio," 462: "homo tantum proficiat, quod sacerdote non indigeat." ${ }^{203}$ Albertus Magnus, "Compilatio," 462: "non debere queri consilium a viris litteratis sive de devotione sive de aliis."

204 Ibid: "Ad idem redit dicere non debere queri consilium a viris litteratis sive de devotione sive de aliis, de eadem presumptione Pelagii est, qui suum sensum consilio scripture preposuit."

205 Albertus Magnus, "Compilatio," 462: "sanctos non oporteat revereri". 
seem to affirm Augustine's fear that Pelagius' conception of Christianity would render the Church obsolete. The heresy Albertus condemns as Pelagian demonstrates a belief in the ability of lay people to achieve salvation outside the Church.

However, other listed heretical beliefs that Albertus attributes to Pelagianism go beyond antinomianism to establish the sanctity of human nature, such that a human soul could unite with God. For example, statement twentyfive asserts that "the soul united to God is deified."206 Albertus' rationale for attributing this heretical belief to Pelagius is that Pelagius considered himself to be "transformed into God by fasting and praying, serving God daily and nightly."207 Another one of the alleged heretical tenets labeled as Pelagian asserts that "man is able, in devotion, to surpass the blessed virgin." ${ }^{208} \mathrm{~A}$ third statement claims that "a soul united with God is deified." 209 It was these assertions that led later scholars to align the heretical beliefs set forth in the Compilatio with the Free Spirit heresy which espouses the belief that human beings can become deified. Therefore, they appear to go beyond the viewpoint that the heretics do not require the Church to assert that they may become one with God and therefore not need a distinct, separate deity to obey. For example, statement seventy-two proposes that man is "admitted to the esteemed divinity

206 Albertus Magnus, "Compilatio," 463: "anima deo unita deificetur".

207 Albertus Magnus, "Compilatio," 463: "Pelagii est, qui putabat se in deum transformari ieiuniis et orationibus serviens deo die ac nocte."

208 Albertus Magnus, "Compilatio," 464: "homo in devotione posset precellere beatam virginem". 209 Ibid., 463: "anima deo unita deificetur". 
and he is given the power of making what he wishes," and statement seventyfour asserts that "man is able to transcend the merit of the blessed virgin and to become God and to not long for God."210 These statements go beyond Augustine and Isidore of Seville's descriptions of Pelagianism and reflect Albertus' attempt to link the heretical views he encountered in the thirteenth century with an ancient heresy, despite the many evident differences.

Pelagianism was referenced by other medieval writers besides Albertus, although it was not one of the most frequently cited ancient heresies. For example, the monk William employs this ancient heresy in his famous debate with the itinerant preacher, Henry, in the 1130s. William labels as Pelagian the heretical belief that children who die unbaptized before the "age of discretion" go to heaven.211 William explains that this viewpoint is heretical because it denies the existence of original $\sin .{ }^{212} \mathrm{He}$ further states that to deny baptism, one must "deny the necessity of benefiting from the death of Christ," which he describes as an error of Pelagius. ${ }^{213}$ Augustine also attributes this viewpoint to Pelagius, and William's words follow Augustine's conception of Pelagius. While none of the heretical statements in the Compilatio discuss baptism of the young, both documents attribute to Pelagius such beliefs that could potentially make the

\footnotetext{
$210 \mathrm{lbid}, 465$ : "[homo] ad amplexum divinitatis et tunc detur potestas faciendi quod vult," and "homo possit transscendere beate virginis meritum et fieri deus et deo non indigere."

211 "Henry: the debate with the monk William, 1133-5," in The Birth of Popular Heresy, ed. R.I. Moore (New York: St. Martin's Press, 1976), 48.

212 lbid.

213 Ibid., 49.
} 
Church unnecessary. Both William and Albertus give voice to a preoccupation that people like Henry and the heretics of the Swabian Ries will make the Church dispensable through their belief that human beings are not hindered by original sin and are even able to become deified. It is this inherently positive view of humanity that both men attribute to Pelagius and then refute in order to prove the necessity of the Church. For if humans are sinners, forever tainted by Adam and Eve's original sin, then they require the Church to guide them from this state.

After Pelagianism, Manichaeism is the second most referenced ancient heresy in the Compilatio. Albertus attributes twelve different statements to the Manichaean heresy. These twelve statements cover various topics, including the resurrection of Christ, confession, sin, and the soul. While some of these statements correspond with conventional definitions of the Manichaean faith, not all of them do. The statements attributed to Manichaeism seem to be a combination of denunciations of church sacraments and discussions of the substance of the soul, largely based upon Augustine's writings about the Manichaeans. In denouncing thirteenth century heresy as "Manichaean," Albertus follows a widespread practice. Jason Beduhn argues that the tradition of terming "any poorly known, heretical group" Manichaean was common not just in medieval Europe, but also in the Middle East and China. ${ }^{214}$

\footnotetext{
214 Jason David Beduhn, The Manichaean Body: In Discipline and Ritual (Baltimore: John Hopkins University Press, 2000), 7.
} 
Manichaeism was founded by a Persian named Mani in the third century C.E. The faith combines elements of both Gnosticism and Zoroastrianism. ${ }^{215}$ Edward Peters, in his discussion of Manichaeism, describes it as a "dualist faith," referring to the two competing powers in the world, good and evil.216 Mani believed that there were two gods - one of darkness and one of light. $\mathrm{He}$ explains the existence of evil in the world through the supposition that the god of darkness stole "sparks of divine light" and locked them inside human bodies. ${ }^{217}$ Humans needed to follow an austere lifestyle in order to release these divine sparks, which according to Mani was the purpose of human existence. BeDuhn contends that the Manichaean faith can be understood more through the actions of its practitioners than philosophical principles. For him, the essence of the Manichaean faith rested in the ascetic discipline and ritual procedures dedicated to releasing the light.218 Dualist beliefs, such as those held by the Manichaeans, alarmed Church writers from the founding of the Church through the Middle Ages. Augustine himself was a devotee of Manichaeism before denouncing it and turning to the Christian Church. He later wrote multiple works against the Manichaean faith. Albertus Magnus seems to base many of his ideas about the Manichaeans on Augustine's writings. In fact, the heresies Albertus attributes to Manichaeism do not appear to follow a thematic trend so much as they follow

215 Peters, Heresy and Authority in Medieval Europe, 32.

216 lbid.

217 lbid.

218 BeDuhn, The Manichaean Body, 21. 
Augustine's specific condemnations of the Manichaeans almost as if following a script.

The first, and most obvious, heretical error that Albertus attributes to the Manichaeans is the belief that the human soul contains the essence of God. Albertus states that the heretics believed that "the soul is made up of the essence of God."219 He attributes this heresy to the Manichaeans, "as Augustine said."220 Further on in the document, Albertus lists a heresy that "the soul is of the substance of God," which he also attributes to Manichaeism.221

Augustine, in his work Concerning Heresies, describes how Manichaeans believed that "both God and the good souls ... are of one and the same nature."222 Unlike Albertus, Augustine also describes the evil nature which Mani believed fought against good in the world. Augustine describes the Manichaean belief that there exist two substances, "good and evil," which engage in "mutual strife and commingling" within the world. ${ }^{223}$ He goes on to explain that the heretics believe that the good souls have been freed from the "contrary nature of the evil souls" and are now made up of the same nature as God.224

Isidore of Seville's description of Manichaeism exhibits considerable similarity to Augustine's. Isidore also describes the Manichaean belief that the

219 Albertus Magnus, "Compilatio,” 462: “... anima sit sumpta de substantia dei”.

220 Ibid., "ut dicit Augustinus".

221 Ibid., "animam esse de substantia dei".

222 St. Augustine, "On Manichaeism” 33.

223 Ibid.

224 lbid. 
soul is made up of the substance of God. He states that Mani believed that "souls flow from God as if from some fountain."225 Like Augustine - and unlike Albertus - Isadore emphasizes the Manichaean belief in an evil substance. He describes the Manichaean belief that "two natures and substances, that is, good and evil" form the world.226 Albertus, in his treatise, only depicts the Manichaean belief that the soul is made of the same essence of God, not their belief in both good and evil forces. The heretical statements that he transcribes in the Compilatio thus may be taken to evidence a belief in the sanctity of human nature, rather than a dualist conception of the world.

Many of the other errors that Albertus ascribes to the Manichaeans pertain to the passion of Christ and the resurrection, including one heretical assertion that "Christ was not resurrected, it is a Manichaean heresy."227 Another contends that "God was not torn in the passion," while a third asserts that "the passion of Christ the Lord should not be remembered."228 A fourth statement about the resurrection asserts that Augustine "demolish[ed]" this Manichaean heresy. ${ }^{229}$ Indeed, Augustine's description of the Manichaeans in his work on heresies does align with Albertus' attribution of these statements to the Manichaeans.

Augustine asserts that the Manichaeans believed that when Christ came to earth

\footnotetext{
225 Isidore of Seville, Etymologies, 176.

226 Ibid.
}

227 Albertus Magnus, "Compilatio," 462: "Christum non resurrexisse, Manicheus est hereticus."

$228 \mathrm{Ibid}, 464-5$ : "deum non laniatum fuisse inpassione," and "non esse memorandam passionem Christi domini et impiissimum et hereticum est, cum nihil ita sit memorandum."

229 Ibid, 462: "error est Manichei, quem destruit Augustinus". 
he did not come in a real body, but came in "the simulated appearance of flesh to deceive human perception."230 Therefore, Christ "feigned not only death, but resurrection as well." 231 Augustine relates this to the Manichaean belief in the divine nature of human souls. He argues that the Manichaeans believed that Christ came not to save bodies, but to save souls which contained a divine spark. ${ }^{232}$ Therefore, in an indirect way these statements attributed to the Swabian heretics repeat the theme of the sanctity of human nature.

Albertus was hardly the only inquisitor to link heresy in the Middle Ages with the Manichaeans of Augustine's time. Heretics were frequently described by inquisitors as Manichaean or as exhibiting characteristics of Manichaeism, and many of them cited the words of Augustine to prove this connection. Most inquisitors who mentioned Manichaeism did so either in relation to the ascetic lifestyle of the heretics they described or to the dualist nature of their beliefs. For example, Adhemar of Chabannes wrote about heretics in Languedoc around 1018. He states that the Manichaeans "appeared" in Aquitaine. ${ }^{233}$ He asserts that they "did not eat meat, as though they were monks, and pretended to be celibate."234 Guibert of Nogent, writing in 1114 about heretics in Soissons, also links their practice of an austere lifestyle to Manichaeism. He states that the

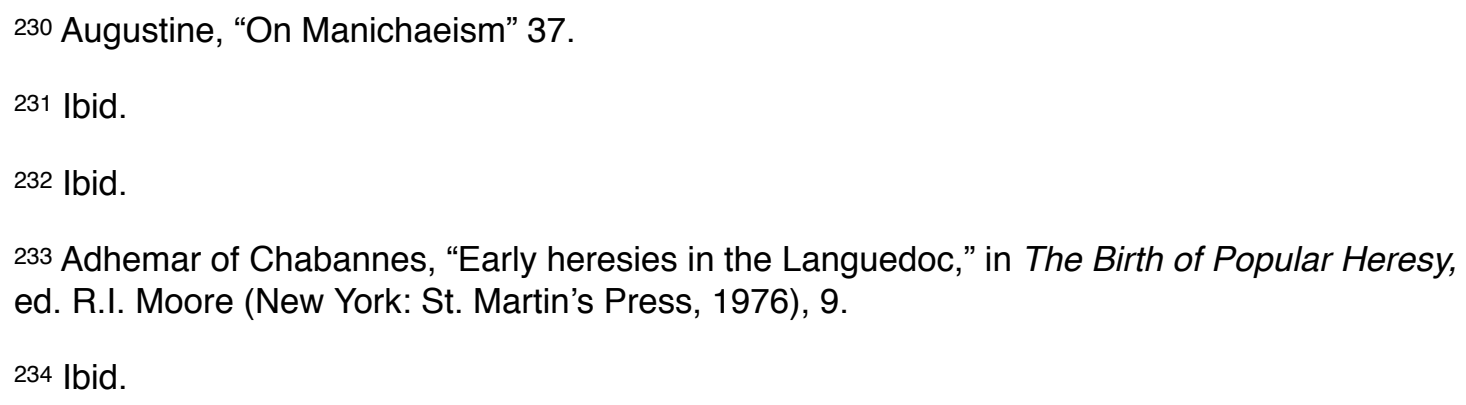


heretics "pride themselves on keeping up the apostolic life" and "esteem only the reading of the Acts of the Apostles." 235 He also clearly bases his categorization of the heretics at Soissons as Manichaeans on Augustine, as he states that "if you review the heresies described by Augustine, you will find this like none of them so much as that of the Manichaeans."236 These inquisitors evidently scoured the pages of Augustine in order to attempt to understand the heresy they believed to be evident in their own world. Many of them seemed to find the most resonance with Augustine's description of the Manichaeans, focusing most heavily on their apostolic lifestyle. Albertus also likely utilized this same text, but attributed heretical viewpoints relating to the sanctity of the human soul to Manichaeans.

With the growing concern about the "Cathar" heresy in Southern France, many inquisitors attributed the dualist beliefs evident there to a continuation of the Manichaean heresy. For example, the book entitled The Higher Star, written around 1235, describes individual sects within "Catharism" and the specific beliefs associated with each sect. The author, Salvo Burci, describes one sect which believes that "all good things are preordained by the good God, all evil things whatsoever by the devil."237 He asserts that the heretics took this belief from the Manichaeans, who, "it is recorded, had spread this wickedness."238

\footnotetext{
235 Guibert of Nogent, "Heretics at Soissons, 1114", in The Birth of Popular Heresy, ed. Moore, 73. 236 Ibid.

237 Salvo Burci, "The Higher Star," in Heresies of the High Middle Ages, ed. Walter L. Wakefield and Austin P. Evans (New York: Columbia University Press, 1969), 275. 238 Ibid.
} 
Another, more explicit, example is Eckbert of Schönau's sermon against the Cathars written in 1165. Eckbert lists multiple errors of the Cathars, which adhere closely to Augustine's descriptions of the Manichaeans. Eckbert states unequivocally that the origins of the Cathar sect come from the "heresiarch Mani" and the Manichaean faith. ${ }^{239}$ One of the aspects of Manichaeism he discusses is dualism. He contends that the Manichaeans teach that "there were two creators, one good and one evil: God and the prince of darkness."240 Eckbert bases these descriptions on Augustine and states that his sermon summarizes Augustine's works on Manichaeism. 241 Therefore, many inquisitors attributed what they identified as contemporary dualist beliefs to a continuation of Manichaeism. They based their understanding of dualism heavily on the writings of Augustine, so the heretical errors they saw bore a strong resemblance to those Augustine recounts of the Manichaeans in the fourth century. While Albertus Magnus also employs Augustine in order to link contemporary heresy with Manichaeism, he showed much less concern with dualism and more concern with the heretics' belief in the sanctity of the human soul and the ability of human beings to achieve salvation outside the Church.

The use of Manichaeism as a term to describe medieval heresy continued after Albertus Magnus wrote the Compilatio. Bernard Gui, in his inquisitorial handbook written in the 1320s (fifty years after the composition of the

239 Eckbert of Schonau, "Semon against the Cathars," in The Birth of Popular Heresy, ed. Moore, 93.

240 Ibid.

241 lbid, 94. 
Compilatio), dedicates an entire chapter to "The Manichaeans of Today."242 Like the other inquisitors, Bernard Gui focuses on the dualist aspects of the Manichaean beliefs. He states that these heretics believed in two gods, "one good and the other bad."243 The evil power created material things, while the good power created "unseen and non-material things." ${ }^{44}$ Bernard Gui also describes how the dualist heretics also believe in two churches - their own good Church and the Roman Church, which they considered to be evil.245 Bernard Gui thus attributes some of the same heretical errors to the "Manichaeans of Today" that Albertus and other earlier inquisitors did. For example, he relates the heretics' belief that Christ "did not have a real human body or real human flesh," and therefore he did not suffer during the passion, rise from the dead, or "ascend into heaven in human bodily flesh."246 Like earlier inquisitors citing Augustine, Gui ascribes an ascetic lifestyle to the dualist heretics. He also relates that they did not eat meat or kill any animal. 247 However, he adds additional practices not found in Augustine or earlier inquisitorial literature. For example, he relates that the heretics "bless a loaf of bread" at the beginning of meals, then keep it in a cloth around their necks before saying the Lord's Prayer and breaking the bread

\footnotetext{
242 Bernard Gui, The Inquisitor's Guide: A Medieval Manual on Heretics, trans. Janet Shirley (Welwyn Garden City: Ravenhall Books, 2006), 35.

243 Ibid.

244 Ibid.

245 Ibid.

246 Ibid., 37.

247 Ibid., 39.
} 
into pieces. ${ }^{248}$ Bernard Gui also discusses a "mark of reverence" called a "melioramentum" that the heretics have to prove their belief. 249

Therefore, later inquisitors who referenced the Manichaeans built upon the words of Augustine and previous inquisitors, but also added additional beliefs to previous ideas about the heretics. The circulation of inquisitorial literature helped form these ideas about the beliefs of medieval heretics, which in many cases were shaped by ideas of early church writers like Augustine. By examining the manner in which inquisitors cited Augustine and his writings on the Manichaeans, historians can understand how inquisitors fit Augustine's words to the heretics they were prosecuting.

Historian Mark Pegg, in The Corruption of Angels, discusses the enduring intellectual tendency to treat heresy as a distinctive and static category, largely unchanging over time. He contends that for medieval people, heresy was an evil, timeless force which has remained constant. Many medieval intellectuals had read Augustine's descriptions of Manichaeism, so they utilized this ancient heresy to characterize any dualist tendencies they encountered in their own era. Pegg, however, warns that it has not only been medieval intellectuals that have fallen victim to this intellectual bias. He advises that many modern historians are also guilty of linking all dualist tendencies together in a genealogical chain stretching back to the original Manichaeans, including the Bogomils in eastern Europe, as well as the good men and good women of the Languedoc. Pegg

248 Ibid.

249 Ibid., 40. 
entreats modern historians to be mindful of this conception of heresy as an enduring an unchanged evil when analyzing the manner in which heresy is classified in medieval sources. ${ }^{250}$

While the Manichaean and Pelagian heresies were the two early heresies most frequently cited by Albertus in the Compilatio, he also mentions many other distinct ancient heresies. Albertus' descriptions of each of them generally follows a thematic trend, and his understanding of the early church heresies can generally be traced back to the writings of either Augustine or Isidore of Seville.

For example, Albertus ascribes four of the Compilatio's heretical statements to the Nestorian heresy. Nestorius, who lived in the fifth century, was accused of dividing Christ's natures between the human and divine elements. ${ }^{251}$ Nestorius asserted that there were two complete natures within Christ, one human and one divine, which were not completely joined. ${ }^{252}$ Even more divisively, Nestorius argued that Christ could not be the Word of God in the flesh. ${ }^{253}$ For Nestorius, it was crucial for the Christian faith that Christ the man suffered the passion. He could not accept that the human man who suffered was also the embodiment of the Word of God.254

250 Pegg, Corruption of Angels, 15-16.

${ }^{251}$ M. Simonetti, "Nestorianism," in Encyclopedia of the Early Church, Volume II, ed. Angelo Di Beradino, trans. Adrian Walford (New York: Oxford University Press, 1992).

252 Daniel A. Keating, "Cyril of Alexandria (C.378-444) and Nestorius of Constantinople (C. 381-C. 451)," in The Student's Companion to the Theologians, ed. Ian S. Markham (Chicester: Wiley Blackwell Publishers, 2013), 56.

253 Ibid., 57.

254 Ibid. 
While Augustine himself does not write about the Nestorians, Isidore of Seville does. Isidore claims that Nestorius (after whom the Nestorians were named) believed that "there was one separate and distinct Son of God and another of humankind."255 In other words, Christ, who was born from the Virgin Mary, was born human, but there came to be a divine Son of God within the human man Jesus. ${ }^{256}$ Following this understanding of Nestorianism, all the statements Albertus designates as Nestorian pertain to either Christ's nature or the passion of the Christ. Some of them adhere quite closely to Isidore's description of Nestorianism. For example, Albertus Magnus attributes to Nestorianism the supposed belief of the Swabian heretics that "the godhead is separated from the body of Christ."257 This adheres closely to Isidore's description of Nestorius' belief that there was "one person of the flesh and the other of the godhead."258 Albertus also describes as Nestorian the alleged belief that "Christ was not a man." ${ }^{259} \mathrm{He}$ relates this to the belief that "Christ did not suffer during the passion."260 Albertus further attributes to Nestorius the heretical belief that "the passion of Christ the Lord should not be remembered."261 His

255 Isidore of Seville, Etymologies, 178.

256 Robert L. Wilken, "Nestorianism," in Encyclopedia of Religion, ed. Lindsay Jones, vol. 10 (Detroit: Macmillan Reference, 2005), 6482.

${ }^{257}$ Albertus Magnus, "Compilatio," 464: "Quod dicitur divinitatem separatam esse a corpore Christi”.

258 Isidore of Seville, Etymologies, 178.

259 Albertus Magnus, "Compilatio," 466: "dicere Christum non doluisse in passione est dicere quod Christus non fuerit homo nisi secundum Phantasma et hoc est heresis Nestorii et Eutychis."

260 Albertus Magnus, "Compilatio," 466: "Dicere Christum non doluisse in passione".

261 lbid: "dicere non esse memorandam passionem Christi domini." 
rationale for this connection stems from the belief that Christ did not suffer during the passion. Therefore, the heretical statements that Albertus attributes to Nestorianism demonstrate a similarity to Isidore of Seville's description of the beliefs of Nestorius and follow the thematic trend of the division of Christ' nature between human and divine. These heretical statements do not, however, seem to follow the trend of referring to the goodness or sanctity of humanity.

Additionally, Albertus designates two of the heretical statements which pertain to sexuality as Jovinian. Jovinian believed there was no particular heavenly reward for virginity, so that married and remarried women had the same worth as virginal women. He even urged consecrated virgins to marry. ${ }^{262}$ David Hunter, in his recent work on the Jovinianist controversy, asserts that Jovinian's overall argument was that "Christian sanctity does not depend on an individual's ascetic merit."263 Since Christ offered salvation to the entire Church, any baptized Christian is entitled to the same heavenly reward. Therefore, individual actions such as "celibacy, fasting, or other ascetic practices" did not matter. ${ }^{264}$ Hunter further contends that while Jovinian was ultimately condemned as heretic, his philosophy was motivated by a concern with the ascetic piety practiced by many other accused heretics. 265 The fourth century, in which Jovinian lived,

\footnotetext{
262 A. Hamman, "Jovinian," in Encyclopedia of the Early Church, Volume I, ed. Di Beradino, trans. Walford.

263 David G. Hunter, Marriage, Celibacy, and Heresy in Ancient Christianity: The Jovinian Controversy (Oxford: Oxford University Press, 2012), 1.

264 Ibid.

265 Ibid., 130.
} 
witnessed an overall increase in asceticism and an increase in accusations of heresy against those who practiced or advocated for an ascetic lifestyle, particularly the Manichaeans. ${ }^{266}$ Jovinian's ideas were consistent with this antiheretical trend.

Both Augustine and Isidore of Seville write about the Jovinians. Augustine relates that Jovinian believed that "all sins are equal, that it is impossible for man to sin after baptism, and that fasts and abstinence from certain kinds of food avail nothing." 267 He goes on to argue that Jovinian "attempted to destroy the virginity of Mary" by asserting that she had had sex while pregnant with Jesus. 268 Additionally, Augustine argues that Jovinian equated the morality of chaste monks and nuns with those who were faithfully married.269 Isidore of Seville, writing about Jovinian 200 years later, builds on these claims somewhat. While Isidore also describes the Jovinian belief that "there is no difference between wives and virgins," he further states that Jovinian believed that there was "no distinction between those who are abstinent and those who carouse unreservedly."270

Albertus Magnus, writing 600 years after Isidore, further exaggerates the sexual freedom allowed by Jovinian. He ascribed alleged heretical statements to

266 lbid.

267 St. Augustine, The De Haeresibus of Saint Augustine, trans. Liguori G. Muller (Washington DC: The Catholic University of America Press, 1956), 117.

268 Ibid.

269 lbid.

270 Isidore of Seville, Etymologies, 177. 
Jovinianism which assert that "a free woman having sex with a free man is not more sinful than those conjoined matrimonially," 271 and that "a virgin is able to be with five boys."272 Jovinianism was an interesting choice of an early church heresy for the Compilatio, because Jovinian preached against an ascetic lifestyle, practiced by the Manichaeans and others, which was also a serious concern among thirteenth-century church writers. However, it would appear that Albertus was mostly utilizing the works of Augustine and Isidore of Seville, which condemn Jovinian for his views on virginity. Albertus seems to be quite concerned with the heretics' belief that engaging in sexual activities was not a sin. Many of the heretical statements pertain to allegations of sexual promiscuity. However, as previously discussed, these types of accusations were frequently utilized against suspected heretics in order to discredit them. So Albertus may have been looking for sources among early church writers to lend credence to his condemnations of the heretics' alleged sexual promiscuity. Among those early church heresies, Jovinianism must have seemed like an apt choice, as both Isidore and Augustine mention his views on sexuality.

The attribution of heretical statements about sex to Jovinian reflects a cursory categorization system within the document. Any heretical belief listed in the Compilatio that reflected sexual immorality was attributed to Jovinian. This classification, however, also shows the occasional inconsistencies in Albertus'

\footnotetext{
271 Albertus Magnus, "Compilatio," 466: "oluta concubendo cum soluto non plus peccat quam admittendo matrimonialiter coniunctum."

272 Ibid., 469: "quinque puerorum virgo possit esse."
} 
thinking, an inconsistency also reflected in other inquisitorial literature. Albertus' approach to this list of alleged heretical beliefs was to classify and then refute them in the most strident terms possible, and he clearly referenced the writings of Isidore of Seville and Augustine to help with this task. Logically, however, it would be difficult to link an entire list of thirteenth-century beliefs with heresies from the fourth and fifth centuries. For example, there is no evidence to support Albertus' assertion that Jovinian believed that a woman could have sex with five boys and still be considered virginal. Even Isidore and Augustine's descriptions of Jovinian's views do not support this connection. However, Albertus believed there to be enough of an association that he could attribute it to Jovinianism. This classification reflects a desire by medieval inquisitors to understand contemporary heresy as belonging to an authentic, unchanging tradition that can be traced back accurately to the words of church fathers.

Among medieval inquisitors, linking contemporary heresy to early church heresies such as Manichaeism was a common tactic. Many utilized the writings of early church writers such as St. Augustine and Isidore of Seville both in order to gain credibility and to help them understand the beliefs of people in their own time period. Albertus Magnus utilizes this tactic frequently throughout the Compilatio. He attributes most of the heretical statements in the document to an early church heresy and these heresies serve as a categorization system throughout the document. Albertus' knowledge of early church heresies can generally be traced to the writings of Augustine and Isidore of Seville. However, how Albertus employs these ideas reveals his concern with the Christians 
achieving salvation outside the church. His selectivity suggests that he was particularly concerned with any views that demonstrated the sanctity of human nature. 


\section{Chapter 3: Pride}

Many of the heresies refuted by Albertus Magnus in the Compilatio concern the heretical belief that lay people could be as holy, if not holier than Church officials, the Virgin Mary, and even God himself. This represents the sin of pride which constituted a central theme in the writings of Augustine and Gregory. One statement recorded in the Compilatio, for example, contends that "man is able to become God," 273 while another contends that "man is able to become equal with God."274 These assertions exhibit the sin of pride, and Albertus Magnus applied particular intensity in his denouncement of this specific heretical idea.

Albertus Magnus cites both Augustine and Gregory the Great throughout the document in order to refute the heretics. He often references their writings on early heresies, but he also refers to their writings on the danger of pride. Albertus utilizes Augustine to condemn the belief that a man who has united his soul with God, is able to raise up others. ${ }^{275}$ He quotes Augustine's statement contending that "when the rank is higher, so much more intense is the fall,"276 which derides pride. He also references Gregory in order to refute the belief that people can achieve a state where they no longer require God.277 He cites

\footnotetext{
273 Albertus Magnus, "Compilatio," 462: “...dicitur quod homo possit fieri deus..." 274 Ibid., 463: “...hominem posse fieri equalem deo.” 275 Ibid., 465. 276 Ibid., 464: “...dicit Augustinus, quod quando altior est gradus tanto profundior est casus.” 277 Ibid., 462.
} 
Gregory's statement that without God, "creation would collapse into nothing" in order to condemn this dangerous assertion. Further, Albertus employs Gregory's writings to invalidate the belief that men united with God are "free from the lessons of Christ."278 He refers to Gregory's statement that "the proof of love is its manifestation in deeds" in order to refute this heretical presumption. ${ }^{279}$ For Gregory and Augustine, pride was a cardinal sin on which they both wrote extensively. Albertus was therefore able to find ample material within their writings with which to denounce this sin in the heretical beliefs set forth in the Compilatio.

The sin of pride is indeed a central theme in Augustine's writings. William Green in his article "Augustine on Pride as the First Sin" opens with the assertion that "Augustine is the most notable ancient defender of the doctrine that pride is the first and basic sin, the cause of Satan's fall and of man's first disobedience."280 Similarly, in the encyclopedia of Augustine's thought, John Cavadini asserts that for Augustine, pride "is the archetypal sin, the original sin from which all other sin proceeds as from a root."281 Cavadini further contends that for Augustine, "pride is the desire to replace God with oneself."282 Many of the heretical statements in the Compilatio adhere, quite literally, to this tendency.

\footnotetext{
278 Ibid., 462: “...quo omnis creatura indiget, quia aliter in nichilum decideret, ut dicit Gregorius...” 279 Ibid, 468: “...Probatio dilecciones exhibido est operis...”

280 William M. Green, Initium Omnis Peccati Superbia: Augustine on Pride as the First Sin (Berkely: University of California Press, 1949), 407.

281 John C. Cavadini, "Pride," in Augustine through the Ages: An Encyclopedia, ed. Allan D. Fitzgerald (Grand Rapids: William B. Eerdmans Publishing Company, 1999), 679. 282 lbid.
} 
Pride, and its opposing virtue, humility, constitute a significant part of Gregory the Great's writings as well. The Moralia of Job especially focuses on the dangers of pride and the importance of humility. George Demacopoulos, in his work on Gregory the Great, contends that Gregory believed that pride was so dangerous because it led humans to distance themselves from God. ${ }^{283}$ Humility is necessary to avoid sin and to lead a life dedicated to God. Demacopoulos further argues that the "balanced antitheses of pride and humility... are at the heart of Gregory's theological outlook."284 Matthew Baasten agrees, asserting in his work on Gregory the Great that "pride is truly the backbone of Gregory's development of the moral life" and even forms the essence of his spirituality. ${ }^{285}$

Pride was not just a central concern for Augustine and Gregory the Great, but was also a central concern of Christian writers from the beginning of Christianity. Writers such as Cassian (d. 435) and Isidore of Seville (d. 636) all treated pride as the root of all sin. Morton Bloomfield, in his treatment of the seven deadly sins, describes the preeminence of pride as the most dangerous sin up through the later Middle Ages. ${ }^{286}$ Bloomfield attributes the centrality of the sin of pride to the medieval ideals of orders and balance. ${ }^{287} \mathrm{He}$ contends that

\footnotetext{
283 George E. Demacopoulos, Gregory the Great: Ascetic, Pastor, and First Man of Rome (Notre Dame: University of Notre Dame Press, 2015), 25.

284 Ibid.

285 Matthew Baasten, Pride According to Gregory the Great : A Study of the Moralia (Lewiston, NY: E. Mellen Press, 1986), 8.

286 Morton W. Bloomfield, The Seven Deadly Sins: an Introduction to the History of a Religious Concept, with Special Reference to Medieval English Literature (East Lansing: Michigan State College Press, 1967), 74.
}

$287 \mathrm{lbid}, 75$. 
pride represented a "rebellion against God, the sin of exaggerated individualism," which was abhorrent to a civilization that valued order and balance. ${ }^{288}$ Bloomfield also emphasizes that pride was considered to upset the "divinely appointed order" and as such constituted the "ultimate heresy."289 Lester Little has contended that by the eleventh century there had occurred a shift from pride to avarice as the most important sin due to the general increase in wealth. This shift is further demonstrated in the apostolic poverty movement. However, Albertus Magnus seems to still be more concerned with pride than avarice, which was consistent with the work of early church writers like Augustine and Gregory.

Many of the references Albertus makes to Augustine's works demonstrate the similarities in their conceptions of pride. For example, in statement forty Albertus relates the heretical belief that "the resurrection is not the future." $290 \mathrm{He}$ attributes this error to the Manichaeans and cites Augustine's work Contra Epistulam Manichaei quam vocant fundamenti to support this assertion. Augustine wrote this work in response to a letter purportedly written by Mani which describes some of the fundamental tenets of Manichaeism. As such, it is written in a similar format to that of the Compilatio.291 In this document, Augustine harshly condemns Mani for taking the title of "Paraclete," which

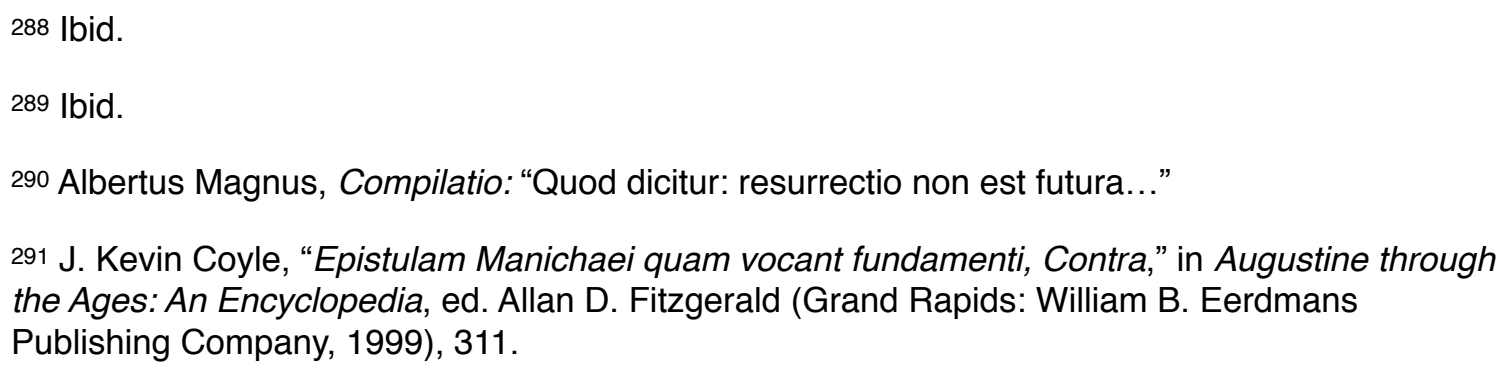


Augustine understands to mean that Mani thought himself to be "taken up by the Holy Spirit."292 This seems to be the link between the thirteenth-century heretical statement that the resurrection is not the future and the Contra Epistulam Manichaei. Augustine argues that Mani wished to be thought of as the reincarnation of the Holy Spirit and an apostle of Jesus Christ, that is, the "one sent by Jesus Christ, who promised to send him."293 If Mani was the reincarnation of the Holy Spirit, then he fulfilled the promise from Jesus Christ of a Second Coming. Therefore, there would be no need for a future resurrection, with Jesus Christ returning to earth.

Augustine explicitly denounces Mani for daring to take on the title of "Paraclete," specifically condemning the pride behind such an action. Augustine writes that "what do we suppose to be the reason of this, but pride, the mother of all heretics?"294 He continues on to label it a "singular audacity" and an "unutterable sacrilege." 295 Albertus Magnus, confronted with heretics who believed themselves to be united with God and above Church law, found an appropriate example to support his refutation of the thirteenth-century heretics in Augustine's condemnation of Mani as a prideful imposter of the Holy Spirit.

\footnotetext{
292 Saint Augustine of Hippo, "Against the Epistle of Manichaeus, Called Fundamental," in $A$ Select Library of the Nicene and Post-Nicene Fathers of the Christian Church, Volume IV: St. Augustine: The Writings against the Manichaeans and Against the Donatists, ed. Philip Schaff (Edinburgh: T\&T Clark, 1887), 132.

293 Ibid.

294 Ibid.

295 lbid.
} 
Many of Albertus' references to Augustine point to works where Augustine enumerates his thinking on original sin and free will. As discussed in the previous chapter, throughout the document, Albertus links the heretics in the Swabian Ries with Pelagius and Pelagianism, and he uses Augustine's writings in order to make this comparison. The references to Pelagius serve to identify the thirteenth-century heretics with the belief that human beings are capable of achieving salvation outside of the church through morality and free will. Similarly, many of Albertus' references to Augustine seem dedicated to disproving the notion that human beings can achieve salvation without the aid of the church or that they can successfully live without sin. For Augustine, the idea that human beings can achieve salvation without both divine assistance and the church sacraments was considered the ultimate sin of pride. Therefore, many of the works of Augustine that Albertus references discuss Augustine's doctrine on original sin and free will and are predicated upon the need for humility.

For example, in statement fifty Albertus relates the heretical belief that "prayers, fasts, and confessions of sin impede a good man."296 He cites Augustine "on infant baptism"297 in order to disprove this. I believe that the work referenced here is Augustine's De peccatorum meretis et remissione peccatorum et de baptismo parvulorum. Augustine wrote this work in response to Pelagius

\footnotetext{
296 "Albertus Magnus, Compilatio, 465: "Dicere quod orationes ieiunia confessiones peccatorum inpediant bonum hominem". 297 Ibid.: "de baptismo parvulorum".
} 
and other writers who shared Pelagius' views on original $\sin .{ }^{298}$ It is divided into three books, of which the first two are the most relevant. In the first book, Augustine argues that Adam's original sin is transmitted to all humans, which means that everyone, even infants, need to be baptized in order to be admitted to heaven. In the second book, he contends that no one, except for Jesus Christ, is able to live without sin. Here, Albertus chose to reference a work that focuses heavily upon Augustine's views on original sin.

The connection between this particular example from Augustine's writings and the heretical belief that human beings do not require confession, fasts, or prayers to reach heaven is not completely linear. De peccatorum meretis et remissione does not discuss the need for prayers, confession, or fasts. However, Augustine does discuss the need for baptism in order to overcome original sin. He writes that "whoever is born of the flesh has need of spiritual regeneration."299 He goes on to explain that men "born in the flesh" are "liable to sin and death from ... Adam," and then must be "born again in baptism associated with righteousness and eternal life." 300 He further argues that there is no Christian who would "allow it to be said, that any one could attain eternal salvation without being born again in Christ," which must be "effected through baptism." 301 This

\footnotetext{
298 Gerald Bonner, "Peccatorum merits et remission peccatorum et de baptismo parvularum, De," in Augustine through the Ages: An Encyclopedia, Fitzgerald, 632.

299 Saint Augustine of Hippo, "A Treatise on the Merits and Forgiveness of Sins, and on the Baptism of Infants," in A Select Library of the Nicene and Post-Nicene Fathers of the Christian Church, Volume V: St. Augustine: Anti-Pelagian Writings, ed. Philip Schaff (Edinburgh: T\&T Clark, 1887), 23.

300 lbid.

$301 \mathrm{lbid}, 23-24$.
} 
doctrine, like the others already discussed, is predicated upon the need for humility. Human beings must admit their sinfulness and submit themselves to God's mercy. I believe that Albertus chose to reference this work because of Augustine's emphasis on original sin and the necessity of baptism to overcome it. Albertus was confronting the heretical belief that church sacraments like confession or religious practices like prayer and fasts were not required for salvation. In response, he cited Augustine's work that enforced the inherent sinfulness of human beings and their need for the Church in order to reach the Kingdom of God.

In statement twenty-four, Albertus references Augustine on the doctrine of free will, which was also a point of contention between Augustine and Pelagius. In this statement, Albertus relates the belief of the heretics in the Swabian Ries that "man united to God is not able to sin." 302 He refutes this belief with the argument that it is "to remove free will from man," and he cites Augustine as proof of this statement. 303 While Albertus does not reference any specific writing by Augustine here, the document referenced above - De peccatorum meretis et remissione - also discusses this topic. In the second book of this work, Augustine states that "there are some persons who presume so much upon the free determination of the human will, as to suppose that it need not sin, and that we require no divine assistance." 304 Augustine refutes this idea by stating that

\footnotetext{
302 Albertus Magnus, Compilatio, 463: "Dicere quod homo unitus deo peccare non possit." 303 Ibid.: "tollere est liberum arbitrium ab homine". 304 Augustine, "A treatise on the Merits and Forgiveness of Sins," 44.
} 
only Jesus Christ "was born without sin," and "lived without sin amid the sins of others." 305 To claim to be without sin, Augustine says, "is to deceive oneself."306 Regarding free will and sin, Augustine contends that human beings need to exercise their free will constantly to avoid temptation, but that even using all our energies, we will still fall into sin. It is only through divine assistance that humans can be freed from $\sin .{ }^{307}$ Therefore, in this statement, Albertus attacks the thirteenth-century heretical notion that humans can achieve a state of being where they are unable to sin by referencing Augustine's fourth-century argument with Pelagius. Augustine's argument is that human beings can never be without sin, and therefore they need to humbly submit to God and the Church in order to free themselves from sin. In this argument, he attributes to Pelagius the idea that humans can achieve salvation solely through exercising their free will. Albertus, pushing the argument further, utilizes this doctrinal dispute in order to disprove the belief that humans can unite with God and become sinless.

Another heretical belief that Albertus refutes with reference to Augustine is the idea that sex and desire are not sins. As previously discussed, sexual immorality was a common incrimination used by inquisitors against accused heretics. Albertus seems to follow this trend when he relays the heretical belief that "a girl is permitted to have sex without stain." ${ }^{08}$ He equates this tenet with

\footnotetext{
305 Ibid., 67

306 Ibid.

307 lbid., 44-45.
}

308 Albertus Magnus, Compilatio, 466: "Dicere quod puerum ex licito concubine pariens sine macula sit". 
the teachings of Julian, a disciple of Pelagius, who, Albertus contended, preached that "desiring is not a stain." ${ }^{09}$ Again, Albertus utilizes the words of Augustine in order to refute a statement in the Compilatio. Here, Albertus references Augustine's book Contra Julianum in order to condemn the belief that sex and desire are not sins.

Augustine wrote Contra Julianum in response to Julian's book, which condemned Augustine's views on marriage and desire. Julian argued that Augustine's contention that any sexual desire is a sin, which was transmitted to humanity through Adam's original sin, results in a condemnation of lawful marriage. ${ }^{310}$ For Julian, desire was a "precondition of sexual union and procreation" and indeed was the "purpose of physical marriage."311 So, while Julian did indeed argue that desire itself is not a sin, he did not allow that all sexual activity was without sin. He believed that excessive desire was reprehensible and needed to be controlled through the institution of marriage..$^{312}$ Augustine, in contrast, argues that all sexual desire is a sin, even in marriage. He allows that although the control of concupiscence through marriage may be "forgiven in comparison with what is worse," 313 desire is nevertheless always

309 Ibid.: "est predicare concupiscenciam maculam non esse, et heresis est cuiusdam Juliani, qui fuit discipulus Pelagii".

310 Mathijs Lamberigts, “Julian of Eclanum," in Augustine through the Ages: An Encyclopedia, ed. Fitzgerald, 478.

311 lbid.

312 Saint Augustine of Hippo, The Fathers of the Church: Saint Augustine: Against Julian, trans. Matthew A. Schumacher (New York: Fathers of the Church, 1957), 142. 313 Ibid., 134. 
sinful. The central tenet of this debate between Julian and Augustine is the doctrine of original sin. Julian did not believe that Adam's original sin was transmitted to all his offspring, especially to newly born infants. ${ }^{314}$

Augustine, in contrast, argued that all humans are born into sin, inherited from Adam and Eve. For Augustine, concupiscence was proof of the sinfulness of humanity. Further, he contends that it is through concupiscence that Adam's Original Sin is transmitted, thus making all human beings tainted by Original Sin from birth. Augustine personally struggled against sexual desire, which he wrote about in his Confessions. He argued that the only way to combat it was through Christ's redemption. Writers such as Julian and Jovinian disagreed and argued that humans could utilize their free will, as well as the institution of marriage, in order to control concupiscence. Augustine's beliefs on Original Sin require Christians to humbly request divine assistance in order to control sexual desire. For Augustine, the belief that human beings could control the effects of concupiscence themselves, without divine intervention, constitutes the sin of pride. Therefore, Augustine argues that all humans need to humbly request divine assistance in order to control sexual desire.

Albertus, in citing this argument, employs Augustine's words for a slightly different purpose. While he is correct that Julian allows that concupiscence itself is not always a sin, Julian did advocate for it to be controlled within marriage. Albertus, however, in order to better fit Augustine's words to the contemporary heresy, uses this argument to condemn sexual activities outside marriage. Here, 
Albertus again utilizes Augustine to condemn human beings presuming to be above church laws, such as the control of concupiscence. While he takes Julian's statements out of context, Albertus does reflect Augustine's viewpoint that sexual desire is always a sin. Although not explicitly in this statement, Albertus also reflects Augustine's doctrine that no one is above God's laws and that all human beings require divine assistance, attained through humbly beseeching God for his mercy.

Despite the commonalities between Augustine, Gregory the Great, and Albertus Magnus' condemnations of pride, the three men, writing in disparate time periods, perceived somewhat different threats to the Church from the sin. An analysis of each writer's treatment of this sin demonstrates their concerns, which are rooted in their own historical circumstances.

Augustine, who lived from 354-430, wrote during a much different era of Christian history than Albertus Magnus. Emperor Constantine had only recently decriminalized Christianity in 313 through the Edict of Milan, and Christianity was still a nascent religion. ${ }^{315}$ In response, Augustine's opinions on pride demonstrate a concern that those in power believe they do not require a Christian God. After all, Emperor Constantine's decriminalization of Christianity had occurred a mere forty-one years before Augustine's birth. Augustine's writings primarily deride those in power, such as the leaders of the Roman Empire, rather than societal dissidents. John C. Cavadini contends that Augustine associated the sin of pride more with "that which is dominant in a 315 Robin Lane Fox, Pagans and Christians (New York: Knopf, 1987), 666-667. 
culture," and not with those who "resist human authority." 316 For example, he specifically condemns the "lust for domination" that "characterized the Roman Empire" as well as the "lust for praise" that "characterized the heroic Roman character as well as the ethos of the schools." 317 Similarly, R.A. Markus describes how Augustine's City of God condemns the Roman Empire as "the very embodiment of pride, of the lust for domination." ${ }^{118}$

One reference to Augustine within the Compilatio reveals some difference between the two authors. Albertus quotes Augustine's statement that "when rank is higher, so much more intense is the fall." 319 This statement seems to refer more to those in power, rather than those opposing the power of the Church. It also fits with Cavadini's assertion that Augustine typically condemned those in power for the sin of pride, not dissidents.

Albertus Magnus, in contrast, utilized this quotation in a different way. Many of the heretical statements refuted in the Compilatio involve lay people circumventing the Church hierarchy, sometimes by taking upon themselves the functions of the Church. In this statement, Albertus relates that the heretics believed that "man united with God can permissibly raise up someone else."320

\footnotetext{
316 Cavadini, "Pride," 679.

317 lbid, 679.

318 Robert A. Markus, "De Civitate Dei: Pride and the Common Good," in Sacred and Secular: Studies on Augustine and Latin Christianity, ed. Robert A. Markus (Aldershot: Variorum, 1994), 252.

319 Compilatio, number 40, "quod dicit Augustinus, quod quando altior est gradus tanto profundior est casus."
}

320 Albertus Magnus, "Compilatio," 465: "homo unitus deo licite possit tollere rem alterius". 
While Augustine was concerned with the pride of those in power, Albertus, as well as other Dominican inquisitors, were concerned with the presumption of lay people acting as Church officials or practicing their Christian faith outside of the Church. For example, one of the other statements asserts that man united to God is better able "to arrive to perfection than 100 cloistered monks." 321 These statements demonstrate prideful behavior by the alleged heretics who presumed to act as Church officials, even asserting their own spiritual superiority above monks. The manner in which Albertus cites both Augustine and Gregory reveals the varying concerns between the different periods in which each author was writing. However, it also reveals the persistent concern with pride among Christian writers, even though it may assume different forms over time.

However, Augustine also spent considerable time and intellectual energy writing against heretics. In this early period of church history, labeling some beliefs and the people who espoused them as heretics helped to define Christian doctrine. Augustine's doctrinal disputes with Pelagius and Julian, among others, helped to define the essence of Christianity, and these debates are still relevant to Christianity as it is practiced today. Augustine also wrote a heresiology, entitled De Haeresibus, which lists eighty-eight heresies and briefly describes them. As Todd Berzon argues, for Augustine and other early church writers, heresiologies functioned as both theological and ethnographic texts. He contends that De haeresibus was an attempt to "manage the content of

$321 \mathrm{lbid}, 467$. "melius est hominem unum ad talem perfectionem [pervenire] quam centum claustra constituere". 
Christianity's counterworld." $322 \mathrm{He}$ further explains that the text "aspires to orient the Christian within a world of enemies through negation and antitypology." 323 Therefore, while Augustine was concerned with the pride of those in power, and those still clinging to pagan beliefs, like Albertus, he also focused on describing heretics and defining them as contrary to the Christian doctrine.

For Gregory, there were two different types of pride - carnal pride and spiritual pride. Matthew Baasten, in his treatment of pride in Gregory's writings, defines carnal pride as that which affects Christians, particularly those in positions of power, and causes them to revel in their own success. Gregory writes that pride can lead men to be lifted up in "conceit above the rest of his fellow creatures" and to "despise their neighbors at their side."324 Carol Straw also describes this type of pride in Gregory's writings. She relates Gregory's view that if those suffering from carnal pride enjoy success, then they believe that "the world's good fortune is a result of their own worthiness." 325 When this happens, they do not thank God for their prosperity, but take pride in their own accomplishments. ${ }^{326}$

Gregory's notion of carnal pride is similar to Augustine's conception of pride. It afflicts primarily those in positions of power within society. Gregory

322 Todd S. Berzon, Classifying Christians: Ethnography, heresiology, and the limits of knowledge in Late Antiquity (Oakland: University of California Press, 2016), 225.

323 Ibid.

324 Baasten, Pride According to Gregory the Great, 39.

325 Carole Ellen Straw, Gregory the Great: Perfection in Imperfection (Berkeley: University of California Press, 1988), 240.

326 lbid. 
witnessed firsthand the horrors resulting from rulers who sought wealth and glory through war and conquest. Born in 540 AD, Gregory lived most of his life in Rome. Rome during the years of Gregory's life was neither peaceful nor stable. Italy was besieged by nearly constant warfare during this period, with invasions from both Gothic tribes and imperial forces. ${ }^{327}$ Rome itself was held under siege numerous times, resulting in famine, disease and depopulation of the city. ${ }^{328}$ The effects of the continuous wars of conquest waged by Gothic tribes and imperial forces attempting to increase their power could only have had a profound impact on Gregory and likely formed his ideas about the dangers of carnal pride.

Gregory also discusses the dangers of spiritual pride. Spiritual pride, as defined by Baasten, generally affects those who are more dedicated to a spiritual life, and causes them to become proud due to their "acquisition of virtue." 329 Gregory warns that the virtuous must be constantly vigilant to avoid this type of pride. ${ }^{330}$ Carol Straw also describes the theme of spiritual balance in Gregory's writings. She characterizes the ideal state of mind for Gregory as "like water apportioned in a balance, the heart of the saint is in equilibrium." 331 Regarding pride, Straw describes Gregory's belief in the necessary balance between virtue and temptation, which helps to regulate between pride and despair. Gregory

\footnotetext{
327 R. A. Markus, Gregory the Great and His World (Cambridge: Cambridge University Press, 1997), 4.

328 Ibid.

329 Baasten, Pride According to Gregory the Great, 44.

330 lbid.

331 Straw, Gregory the Great, 244.
} 
contends that it is spiritual virtue which keeps in check the "carnal excess of sin and despair caused by $\sin . " 332$ Conversely, he argues that it is temptation that keeps in check "spiritual excess and pride by making the soul humble."333 Similarly, Baasten argues that Gregory believes that the spiritually proud become "blinded by the illusion of their own strength," and in this illusion they forget that their strength comes not from themselves, but from the grace of God. ${ }^{334}$ Baasten quotes Gregory on this topic stating that the spiritually proud individual "increasing in the sin of pride ... sees himself up above all," including God. ${ }^{335}$ It is this type of pride that Albertus is most concerned with in his refutation of the heretics from the Swabian Ries. Indeed, that description could easily apply to the heretical statements Albertus condemns in the Compilatio.

The experiences of Gregory's life likely informed these views as well. Before becoming pope, Gregory lived an austere life as a monk. However, he was drawn out of this contemplative life into an active life of public service, despite his desire to remain a monk and his unwillingness to accept the role of pope. R.A. Markus argues that Gregory felt inadequate to the responsibilities involved in the papal office. Additionally, Gregory preferred the quiet contemplative life to the "tempestuous sea of world affairs." 336 This tension

\footnotetext{
332 Ibid., 245.

333 lbid.

334 Baasten, Pride According to Gregory the Great, 47.

335 Ibid., 48.

336 Markus, Gregory the Great and His World, 13.
} 
between the active and the contemplative life is evident in many of Gregory's writings. Markus argues that Gregory resolved this conflict in his own life by humble obedience to God's will through public service. ${ }^{337}$ Gregory attempted to follow Christ's example in this. He wrote that while the contemplative life differs greatly from the active, the "Redeemer coming in the flesh and leading both, combined them in himself." 338 For Gregory, both the active and the contemplative life were necessary to be a good Christian. His writings on spiritual pride reflect this viewpoint, as he considers that merely acquiring virtue without either experiencing temptation or conducting charity towards others leads to the sin of pride.

An example from the Compilatio demonstrates both the similarities and differences between Albertus' and Gregory's conceptions of pride and their concerns about the Church. Albertus states that the Swabian heretics believe themselves to be "free from the lessons of Christ." ${ }^{339}$ Albertus asserts that this is a "lie in true doctrine" and cites both the Bible and Gregory the Great as proof of this assertion. ${ }^{340} \mathrm{He}$ utilizes two quotations from Gregory's Homily thirty to support his point. The first is that "the proof of love is its manifestation in deeds," and the second is "let him examine his words, his thoughts, and his life

\footnotetext{
337 Ibid, 20.

$338 \mathrm{lbid}, 21$.

339 Albertus Magnus, Compilatio, 468: "Dicere hominem liberum esse a Christi preceptis..." 340 Ibid.: "...mendacium est in doctrina veritatis..."
} 
concerning the love of his creator." 341 The second quotation has been paraphrased somewhat, but is close enough to determine its origin. Carole Straw interprets this Homily as a lesson that the love of God is shown through deeds. In order to achieve a balanced life dedicated to God, Straw argues, one must resist pleasure. ${ }^{342}$

As previously discussed, Gregory valued balance as a central component of his Christianity. For Gregory, a significant tension that required a difficult balance was the tension between an ascetic life and one of public service. Gregory believed that Christianity necessitated "an authentic, convincing, and lifelong commitment" to humility, which could only be achieved through "ascetic detachment." 343 He enjoyed his time as a monk, living a quiet, contemplative life. However, Gregory also felt considerable civic responsibility and believed that capable men should not remain in monasteries, but "must hear the call to serve." 344 Gregory argued that a true ascetic actually "cared so little about himself" that he would "willingly suspend his own enjoyment of the contemplative life to be of service to others." 345 This is indeed what Gregory himself did - he left the sanctuary of the monastery in order to become pope during an exceptionally turbulent time for Rome. He served God through his service to the

\footnotetext{
341 Ibid.: "Probatio dilectionis exhibido est operis, et ibidem de dilectione conditoris, lingua (?) manus requiratur."

342 Straw, Perfection in Imperfection, 120.

343 Demacopoulos, Gregory the Great, 10.

344 Ibid.

345 lbid., 19.
} 
Christian realm, and through his deeds. Historians who write about Gregory discuss the impact this tension between the contemplative life and an active life of service had upon Gregory and his worldview, which is demonstrated through his writings. It is reasonable to assume that Gregory's statement that one's love of God should be shown through deeds reflects this tension within his own life and his spiritual outlook.

Albertus, however, utilized Gregory's quotation in a slightly different manner. Rather than advocating a life of active service to God, Albertus argues that the Swabian heretics should not consider themselves to be above God's laws. Gregory, living in a world where the safety and security of Rome was daily under threat, evidenced more concern with how Christians could best serve God. Albertus, faced with heretics inflated with so much pride that they thought themselves to be more holy than the Church, was more concerned with advocating adherence to Church laws and humble obedience to the Word of God.

Throughout the Compilatio, Albertus Magnus is concerned with the belief that people can become so holy that they are no longer required to follow Church laws nor even need the Church to achieve salvation. This belief is rooted in the sin of pride, which was a significant concern, not just for clerics in the thirteenth century, but also for early Church writers like Augustine and Gregory the Great. Albertus utilizes these writers in order to demonstrate the sinfulness and error behind the heretical statements he sets forth in the Compilatio. An analysis of how Albertus utilizes the writings of Gregory and Augustine, specifically 
surrounding the sin of pride, reveals the different concerns each author had about the Church and Christianity during their lifetime. Writing in a period when Christianity was still a young religion, Augustine demonstrates concern that those in power will not believe that they require Christianity. Gregory, writing during a period of turmoil for Rome, advocates a life of balance where not only do those in power need the humility of obedience to God, but also that those living a life of spiritual contemplation need to experience temptation in order to achieve humility. He argues that Christianity requires active service to God, not merely ascetic piety. Albertus Magnus, living during an era when many Christians adhered to the vita apostolica and practiced Christianity outside the bounds of the Church, expresses concern that Christians still need the Church and its laws in order to achieve salvation. All three writers were concerned with the sin of pride, but their conception of this sin was rooted in the particular circumstances of the eras in which they lived.

Despite the differences between their conceptions of pride, this analysis demonstrates the consistent concern of Church writers with the sin of pride. In Augustine's writings, his condemnation of pride fosters the necessity for a humble dedication to God in Christian doctrine. In Gregory's writings, it serves to instill dedication to the Christian community. In the thirteenth and fourteenth centuries, Albertus and other inquisitors used pride to incriminate those accused of heresy. While the danger from the sin of pride has been continuously emphasized throughout the history of Christianity, the struggle to combat it 
helped to formulate Christian doctrine and the very essence of medieval Christianity. 


\section{Conclusion}

In conclusion, the Compilatio, written by Albertus Magnus in thirteenthcentury Germany, provides insight into the viewpoints and preoccupations of a Dominican friar. The historical events surrounding the composition of this document - medieval heresy and the struggle to combat it - have been often studied and frequently debated by historians, but there are still many unanswered questions concerning the events of this era. An in-depth analysis of the writings of the inquisitors who strived to prevent the spread of the insidious disease of heresy, which may or may not have existed at all, is valuable in providing a better understanding of this time period.

From the extensive historiography on heresy, historians have learned to be cautious when approaching the study of heretical groups. My study of the Compilatio is no different. The Compilatio was most likely written by Albertus Magnus after the actual inquisition in the Swabian Ries had taken place. Thus, his reactions were likely based on the listed statements sent to him by another inquisitor. So, the statements in the Compilatio were filtered through at least one other witness before they came to Albertus, who also may not have transmitted them exactly. Modern readers of the Compilatio should therefore be careful about accepting the statements set forth in the document as actual beliefs of a defined heretical sect. What historians can certainly analyze from the document, however, is the thinking of a Dominican inquisitor.

The period in which the Compilatio was written witnessed significant religious changes. Reformations during the eleventh and twelfth centuries had 
fueled anti-clerical sentiment and the desire for a more personal faith among many lay practitioners. One avenue for those seeking a more active role in their own faith was through the imitation of the apostles. These people looked to their example in the Bible, and so they sought to live a life dedicated to poverty, mendicancy, and preaching. Those dedicated to this vita apostolica sometimes fell into conflict with the established Church and were occasionally tried for heresy. The communities of beguines and beghards were of particular concern to the Church. These people founded semi-monastic communities, which were not controlled by a monastic rule and were frequently the target of condemnation from Church councils. Similarly, the Church in this period displayed concern with those practicing Christianity outside the rules and law of the hierarchical Church. The heretical statements condemned by Albertus Magnus in the Compilatio depict lay people who were supposedly practicing Christianity outside of the Church in a way that would have seriously undercut its authority.

Another theme of many lay practitioners' faith during this period was mysticism, or experiencing direct interactions with God. Mystical interactions with God allowed those with less education, particularly women, to practice their faith outside of the Church. While some who practiced mysticism were accused of heresy, others were considered religious authorities or even canonized as saints. A few of these mystics tended toward antinomianism, which is the belief that souls who attained perfection were no longer required to follow Church laws. This belief, which is prominent among the statements in the Compilatio, was of particular concern to Church authorities. Some historians have labeled the 
Compilatio as the forerunner to the "Free Spirit Heresy." The supposed heresy of the Free Spirits was predicated upon antinomian beliefs. However, historians have now come to the conclusion that the Free Spirits did not actually exist, but that similar beliefs were instead confined to a spiritual tendency among a few individuals or small groups. The virulent response from the Church against this heresy of the Free Spirit, despite the lack of evidence for its existence, is a testament to the fear inspired by antinomian views. Albertus Magnus also harshly condemns the antinomian beliefs set forth in the Compilatio. Many of them express a disregard for Church laws while others reveal a propensity to seek salvation outside the Church hierarchy.

The Dominican Order played a significant role in the fight against heresy in the thirteenth century. The order was founded upon the apostolic ideal; they provided an avenue for practitioners of the vita apostolica to join the Church and a way to integrate the apostolic life into the Church. Their mission made them an ideal tool of the papacy to combat heresy, as they themselves adhered to many of the same ideals as lay practitioners. Indeed, the papacy utilized the Dominican order often in their continuous fight against heresy. These inquisitors, many of whom belonged to the Dominican Order, accumulated a considerable amount of inquisitorial literature, which they shared amongst themselves. One effect of this shared body of literature was that it served to unify the inquisitorial response, with many inquisitors utilizing common tactics in their fight against heresy. 
Albertus Magnus follows this trend. His refutations of these heretical statements exhibit similar intellectual tendencies to the inquisitorial literature from the time. For instance, Albertus Magnus associates many of the statements with ancient heresies, according to his understanding of these early beliefs. These associations serve as a system of categorization throughout the document. Like many other inquisitors, Albertus Magnus cited the Bible, Augustine, and Gregory the Great in his writings against heresy. He utilized these writers to lend credence to his argument, but they also shaped his views on heresy. Albertus attempted to fit early church heresies, and the views of the early church writers, to the religious situation in the thirteenth century. The manner in which he employs these sources betrays his preoccupations. Specifically, Albertus focuses primarily upon refuting the idea that Christians can achieve salvation outside of the Church and that humans can achieve a state of perfection where they no longer require the Church or its laws. He utilized the writings of early church writers like Augustine in order to form his response to these heretical views.

Additionally, many of the statements set forth in the Compilatio demonstrate the sin of pride. Albertus' condemnation of these prideful tendencies is central to his response to the heresies the Compilatio describes. He relies heavily upon the writings by Augustine and Gregory the Great on pride in order to formulate his response to the heretical statements. Albertus' conception of this sin differs from both Gregory and Augustine, owing largely to the different historical and personal circumstances of each writer. Augustine 
generally associates the sin of pride with those in power, while Gregory

associates it with both those in power and those who allow their spirituality to turn to pride. Albertus Magnus, in contrast, accused a small group of lay people of heresy and prideful behavior. These heretics reportedly practiced their faith outside the traditional channels of the Church, took upon themselves the functions of the clergy, disregarded Church law, and even labeled themselves as godly. In an era when many lay people practiced the vita apostolica outside the confines of the Church, these actions were considered a significant threat to its authority. For Albertus Magnus, these beliefs also constituted the ultimate sin of pride. He utilizes pride to formulate the backbone of his condemnation of these statements.

Other medieval inquisitors also depicted the pride of the accused heretics in their own sanctity. For example, the Dominican friar Stephen Bourbon (d. 1261) describes the beliefs of the Waldensians that "any good man is the son of God, just as Christ is." 346 Bourbon lists one of the reasons that the Waldensians acquired this error as "arrogance."347 Bernard Gui also depicts the pride of the heretics in their own sanctity. For example, he argued that the heretics consider themselves to be successors of the apostles and so "vaunt themselves vainly" and boast that they "maintain and observe evangelical and apostolic poverty." 348

\footnotetext{
346 Stephen Bourbon, "Waldenses in the Thirteenth Century," in Heresies of the High Middle Ages, ed. Wakefield and Evans, 350.

347 Ibid.

348 Bernard Gui, "The Conduct of the Inquisition of Heretical Depravity," Heresies of the High Middle Ages, ed. Wakefield and Evans, 391.
} 
He contends that along with "boldly declaring that they were imitators and successors of these apostles," they also then "cast aspersions upon prelates and clergy for abundant wealth and lives of luxury." $349 \mathrm{He}$ further contends that the heretics taught that "they who call themselves apostles of Christ, they and none other, have the power which the blessed apostle Peter received from God."350 These statements depict the sin of pride evident within the words of the accused heretics and display concern with the heretics' belief that their own sanctity is much greater than that of the Church and its officials.

Pride was central to Albertus' own response to heresy. He cites the sin of pride in order to condemn those accused of heresy for taking upon themselves functions of the Church and seeking salvation outside the Church's path. Although Albertus' conception of pride was different from Augustine and Gregory, owing to the different circumstances of his life and times, he utilized their writings to formulate his response to thirteenth-century heresy. Through an analysis of the concept of pride, we can see how he began with the examples of the church fathers, and built upon and adapted their conceptions of pride, to fit the religious practices he believed constituted heresy in the Swabian Ries.

This analysis also demonstrates how Albertus Magnus conceived of heresy as an unchanging tradition, which could be traced back to the writings of the church fathers. Albertus did not question the veracity of Augustine's depictions of heresy, nor did he question the connection between Augustine's

349 lbid., 387. 350 lbid., 405. 
descriptions and the heretics he saw in the thirteenth century. For Albertus, this provided evidence that the threat of heresy remained largely unchanged from Augustine's time to his own, despite the obvious differences in historical circumstances. With this conviction, he was able to directly link the heretical statements in the Compilatio with fourth and fifth century heresies. 


\section{Bibliography}

Albertus Magnus. "Compilatio de novo spiritu." In Geschichte der deutschen Mystik im Mittelalter. Edited by Wilhelm Preger, 461-471. Leipzig: Dorffling und Franke, 1874-1893.

Ames, Christine Caldwell. Righteous Persecution: Inquisition, Dominicans, and Christianity in the Middle Ages. Philadelphia: University of Pennsylvania Press, 2011.

Anzulewicz, Henryk. "Albertus Magnus, Saint." In Complete Dictionary of Scientific Biography. Volume 19, 99-103. Detroit: Charles Scribener's Sons, 2008.

Arnold, John H. Inquisition and Power: Catharism and the Confessing Subject in Medieval Languedoc. Philadelphia: University of Pennsylvania, 2001.

Augustine of Hippo. "Against the Epistle of Manichaeus, Called Fundamental." In A Select Library of the Nicene and Post-Nicene Fathers of the Christian Church, Volume IV: St. Augustin: The Writings against the Manichaeans and Against the Donatists, edited by Philip Schaff, 129-150. Edinburgh: T\&T Clark, 1887.

. The De Haeresibus of Saint Augustine. Translated by Reverend Liguori G. Muller. Washington DC: The Catholic University of America Press, 1956.

. The Fathers of the Church: Saint Augustine: Against Julian, Translated by Matthew A. Schumacher. New York: Fathers of the Church, 1957.

"On Nature and Grace." In Selected Writings on Grace and Pelagianism. Translated by Roland Teske. New York: New City Press, 2011.

"A Treatise on the Merits and Forgiveness of Sins, and on the Baptism of Infants." In A Select Library of the Nicene and Post-Nicene Fathers of the Christian Church, Volume V: St. Augustine: Anti-Pelagian Writings, edited by Philip Schaff. 15-79. Edinburgh: T\&T Clark, 1887.

Baasten, Matthew. Pride According to Gregory the Great : A Study of the Moralia. Lewiston, NY: E. Mellen Press, 1986. 
Bailey, Michael. Battling Demons: Witchcraft, Heresy, and Reform in the Late Middle Ages. University Park: The Pennsylvania State University Press, 2003.

Bernard Gui. The Inquisitor's Guide: A Medieval Manual on Heretics. Translated by Janet Shirley. Welwyn Garden City: Ravenhall Books, 2006.

Bloomfield, Morton W. The Seven Deadly Sins: an Introduction to the History of a Religious Concept, with Special Reference to Medieval English Literature. East Lansing: Michigan State College Press, 1967.

Cohn, Norman. The Pursuit of the Millennium: Revolutionary Millenarians and Mystical Anarchists of the Middle Ages. London: Maurice Temple Smith, 1970.

Constable, Giles. The Reformation of the Twelfth Century. Cambridge: Cambridge University Press.

Demacopoulos, George E. Gregory the Great: Ascetic, Pastor, and First Man of Rome. Notre Dame: University of Notre Dame Press, 2015.

Epstein, Steven A. "Urban Society." In The New Cambridge Medieval History, Vol. 5 c. 1198-1300, edited by David Abulafia, 26-37. Cambridge: Cambridge University Press, 1999.

Farmer, Sharon. Surviving Poverty in Medieval Paris: Gender, Ideology, and the Daily Lives of the Poor. Ithaca: Cornell University Press, 2002.

Fitzgerald, Allan D, ed. Augustine through the Ages: An Encyclopedia. Grand Rapids: William B. Eerdmans Publishing Company, 1999.

Fox, Robin Lane. Pagans and Christians. New York: Knopf, 1987.

Freed, John B. The Friars and German Society in the Thirteenth Century. Cambridge: The Medieval Academy of America, 1977.

Given, James B. Inquisition and Medieval Society. Ithaca: Cornell University Press, 1997.

Green, William M. Initium Omnis Peccati Superbia: Augustine on Pride as the First Sin. Berkely: University of California Press, 1949.

Grundmann, Herbert. Religious Movements in the Middle Ages: The Historical Links between Heresy, the Mendicant Orders, and the Women's Religious Movement in the Twelfth and Thirteenth Century, with the Historical 
Foundations of German Mysticism. Translated by Steven Rowan. Notre Dame: University of Notre Dame Press, 1995.

Hamman, A. "Jovinian." In Encyclopedia of the Early Church. Volume I. Edited by Angelo Di Beradino. Translated by Adrian Walford, 454. New York: Oxford University Press, 1992.

Hunter, David G. Marriage, Celibacy, and Heresy in Ancient Christianity: The Jovianist Controversy. Oxford: Oxford University Press, 2012.

Isidore of Seville. The Etymologies of Isidore of Seville, edited by Stephen A. Barney, et al. Cambridge: Cambridge University Press, 2010.

Keating, Daniel A. "Cyril of Alexandria (C.378-444) and Nestorius of Constantinople (C. 381-C.451)." In The Student's Companion to the Theologians, edited by lan S. Markham, 48-59. Chichester: Wiley Blackwell Publishers, 2013.

Keech, Dominic. The Anti-Pelagian Christology of Augustine of Hippo, 396-430. Oxford: Oxford University Press, 2012.

Kieckhefer, Richard. Repression of Heresy in Medieval Germany. Philadelphia: University of Pennsylvania Press, 1979.

Lambert, Malcolm. Medieval Heresy: Popular Movements from the Gregorian Reform to the Reformation. 3rd edition. Malden, MA: Blackwell Pub., 2002.

Lamm, Julia A, ed. The Wiley-Blackwell Companion to Christian Mysticism. Chichester: Wiley Publishing, 2012.

Lawrence, C.H. Friars: The Impact of the Mendicant Orders on Medieval Society. London: I.B. Tauris, 2013.

Lerner, Robert E. The Heresy of the Free Spirit in the Later Middle Ages. Berkeley: University of California Press, 1972.

Libera, Alain de. "Albertus Magnus." In Routledge Encyclopedia of Philosophy. Volume 1, 145-152. Edited by Edward Craig. London: Routledge Press, 1998.

Maier, Christoph T. Preaching the Crusades: Mendicant friars and the Cross in the Thirteenth Century. Cambridge: Cambridge University Press, 1994.

Markus, Robert A. "De Civitate Dei: Pride and the Common Good." In Sacred and 
Secular: Studies on Augustine and Latin Christianity, edited by Robert A. Markus. Aldershot: Variorum, 1994.

. Gregory the Great and His World. Cambridge: Cambridge University Press, 1997.

McFarland, Ian A. The Cambridge Dictionary of Christian Theology. Cambridge: Cambridge University Press, 2011.

McGinn, Bernard. The Presence of God: A History of Western Christian Mysticism. New York: Crossroads Publishing, 1998.

Miller, Clyde Lee. "Albertus Magnus (ca. 1200-1280)." In Medieval Germany: An Encyclopedia, edited by John M. Jeep, 8-10. New York: Garland Publishing, 2001.

Moore, R.I. The Birth of Popular Heresy. New York: St. Martin's Press, 1976.

. The Formation of a Persecuting Society: Authority and Deviance in Western Europe, 950-1250. Malden, MA: Blackwell Publishing, 2007.

. War on Heresy Faith and Power in Medieval Europe. Cumberland: Harvard University Press, 2012.

Pegg, Mark Gregory. A Most Holy War: The Albigensian Crusade and the Battle for Christendom. Oxford: Oxford University Press, 2008.

Pelster, Franz. "Albert der Grosse und der Tractatus de inquisitione haereticorum." Zeitschrift Für Katholische, 45 (1921): 609-627.

Peters, Edward, ed. Heresy and Authority in Medieval Europe: Documents in Translation. Philadelphia: University of Pennsylvania Press, 1980.

Preger, Wilhelm. "Der Traktat des David von Augsburg über die Waldenser, Abhandlungen der Bayerischen Akademie der Wissenschaften, Historische Klasse 18 (1878): 181-235.

Resnick, Irvin M., and Kenneth F. Kitchell, Jr., eds. Albert the Great: Selectively Annotated Bibliography (1900-2000). Tempe: Arizona Center for Medieval and Renaissance Studies, 2004.

Russell, Jeffrey Burton. Dissent and Reform in the Early Middle Ages. Berkeley: University of California Press, 1965.

Simonetti, M. "Nestorianism." In Encyclopedia of the Early Church. Volume II. 
York:

Edited by Angelo Di Beradino. Translated by Adrian Walford, 594. New Oxford University Press, 1992.

Simons, Walter. City of Ladies: Beguine Communities in the Medieval Low Countries, 1200-1565. Philadelphia: University of Pennsylvania Press, 2003.

Straw, Carole Ellen. Gregory the Great: Perfection in Imperfection. Berkeley: University of California Press, 1988.

Sullivan, Karen. The Inner Lives of Medieval Inquisitors. Chicago: The University of Chicago Press, 2011.

Vauchez, Andre. "The Religious Orders." In The New Cambridge Medieval History, Volume V c. 1198-1300, edited by David Abulafia, 182-203. Cambridge: Cambridge University Press, 1999.

Wakefield, Walter L., "Notes on Some Antiheretical Writings of the Thirteenth Century." Franciscan Studies 27 (1967): 285-321.

Wakefield, Walter L. and Austin P. Evans, eds. Heresies of the High Middle Ages. New York: Columbia University Press, 1969.

Watt, J.A. "The Papacy." In The New Cambridge Medieval History, Volume V c. 1198-1300, edited by David Abulafia, 107-163. Cambridge: Cambridge University Press, 1999.

Weisheipl, James A. "Albertus Magnus." In Dictionary of the Middle Ages, edited by Joseph Strayer, 126-130. New York: Charles Scribner's Sons, 1982.

Wilken, Robert L. "Nestorianism." In Encyclopedia of Religion. Volume 10, edited by Lindsay Jones, 6482-6483. Detroit: Macmillan Reference, 2005. 